\title{
Thermal processes of thermokarst lakes in the continuous permafrost zone of northern Siberia - observations and modeling (Lena River Delta, Siberia)
}

\author{
J. Boike ${ }^{1}$, C. Georgi ${ }^{1}$, G. Kirilin ${ }^{2}$, S. Muster ${ }^{1}$, K. Abramova ${ }^{3}$, I. Fedorova ${ }^{4,5,6}$, A. Chetverova ${ }^{4,5}$, M. Grigoriev ${ }^{7}$, \\ N. Bornemann ${ }^{1}$, and M. Langer ${ }^{1,8}$ \\ ${ }^{1}$ Alfred Wegener Institute Helmholtz Center for Polar and Marine Research, Telegrafenberg A43, 14473 Potsdam, Germany \\ ${ }^{2}$ Leibniz-Institute of Freshwater Ecology and Inland Fisheries (IGB), Mueggelseedamm 310, 12587 Berlin, Germany \\ ${ }^{3}$ Lena Delta Nature Reserve, Ak. Fedorova 28, 678400 Tiksi, Sakha Republic, Russia \\ ${ }^{4}$ Institute of Earth Science, Saint-Petersburg State University, 10th line of Vasiljevsky Island, 33-35, 199178 \\ Saint-Petersburg, Russia \\ ${ }^{5}$ Arctic and Antarctic Research Institute, 38, Beringa Str., St. Petersburg, 199397, Russia \\ ${ }^{6}$ Kazan Federal University, 18, Kremlyovskaya str., Kazan, Russia \\ ${ }^{7}$ Melnikov Permafrost Institute, Siberian Branch, Russian Academy of Sciences, Yakutsk, Russia \\ ${ }^{8}$ Laboratoire de Glaciologie et Géophysique de l'Environnement (LGGE), 38402 St Martin d'Hères, CEDEX, France
}

Correspondence to: J. Boike (julia.boike@awi.de)

Received: 16 April 2015 - Published in Biogeosciences Discuss.: 30 April 2015

Revised: 1 October 2015 - Accepted: 2 October 2015 - Published: 19 October 2015

\begin{abstract}
Thermokarst lakes are typical features of the northern permafrost ecosystems, and play an important role in the thermal exchange between atmosphere and subsurface. The objective of this study is to describe the main thermal processes of the lakes and to quantify the heat exchange with the underlying sediments. The thermal regimes of five lakes located within the continuous permafrost zone of northern Siberia (Lena River Delta) were investigated using hourly water temperature and water level records covering a 3-year period (2009-2012), together with bathymetric survey data. The lakes included thermokarst lakes located on Holocene river terraces that may be connected to Lena River water during spring flooding, and a thermokarst lake located on deposits of the Pleistocene Ice Complex. Lakes were covered by ice up to $2 \mathrm{~m}$ thick that persisted for more than 7 months of the year, from October until about mid-June. Lake-bottom temperatures increased at the start of the ice-covered period due to upward-directed heat flux from the underlying thawed sediment. Prior to ice break-up, solar radiation effectively warmed the water beneath the ice cover and induced convective mixing. Ice break-up started at the beginning of June and lasted until the middle or end of June. Mixing occurred
\end{abstract}

within the entire water column from the start of ice breakup and continued during the ice-free periods, as confirmed by the Wedderburn numbers, a quantitative measure of the balance between wind mixing and stratification that is important for describing the biogeochemical cycles of lakes. The lake thermal regime was modeled numerically using the FLake model. The model demonstrated good agreement with observations with regard to the mean lake temperature, with a good reproduction of the summer stratification during the ice-free period, but poor agreement during the ice-covered period. Modeled sensitivity to lake depth demonstrated that lakes in this climatic zone with mean depths $>5 \mathrm{~m}$ develop continuous stratification in summer for at least 1 month. The modeled vertical heat flux across the bottom sediment tends towards an annual mean of zero, with maximum downward fluxes of about $5 \mathrm{~W} \mathrm{~m}^{-2}$ in summer and with heat released back into the water column at a rate of less than $1 \mathrm{~W} \mathrm{~m}^{-2}$ during the ice-covered period.

The lakes are shown to be efficient heat absorbers and effectively distribute the heat through mixing. Monthly bottom water temperatures during the ice-free period range up to $15^{\circ} \mathrm{C}$ and are therefore higher than the associated monthly 
air or ground temperatures in the surrounding frozen permafrost landscape. The investigated lakes remain unfrozen at depth, with mean annual lake-bottom temperatures of between 2.7 and $4{ }^{\circ} \mathrm{C}$.

\section{Introduction}

Lakes can be interpreted as sensitive climatic indicators that respond to a range of different influences affecting the world's climate. They can also exert an important influence on the local, regional, and global climate and hydrology by regulating heat and water fluxes, but their thermal dynamic represented in RCMs and GCMs is rather simple, and does not include all physical processes that are necessary for reproducing atmosphere-lake interaction (Walsh et al., 1998; Martynov et al., 2012). Lakes are often typical features of Northern Hemisphere ecosystems (Fig. 1). In permafrost areas, which occupy about $25 \%$ of the world's landmass, lakes influence not only the thermal regime of the surrounding and underlying permafrost, but also the atmospheric heat and water fluxes, due to their large thermal heat reservoirs and heat capacities. The winter heat flux into the atmosphere through the ice cover from deep lakes that remain unfrozen at depth is several times greater than that from the surrounding tundra (Jeffries et al., 1999). Even smaller polygonal water bodies (thermokarst ponds), which freeze to the bottom every winter, have heat fluxes that are an order of magnitude greater than those from the surrounding permafrost (Langer et al., 2011b). The large thermal heat reservoir in lakes prevents the sediment beneath those lakes with a water depth greater than about 2 or $3 \mathrm{~m}$ from freezing, thus allowing a talik to develop (Lachenbruch, 1962). However, few data exist on the thermal conditions of lakes in north and central Yakutia, or the taliks beneath them (Grigoriev, 1960, 1966; Are, 1974; Pavlov et al., 1981). These unfrozen layers of lake sediment can enhance mobilization of the carbon reservoir by enabling year-round microbial decomposition in otherwise frozen surroundings, and water bodies can thus be hotspots for $\mathrm{CO}_{2}$ and $\mathrm{CH}_{4}$ emissions (Langer et al., 2015; Schneider von Deimling et al., 2015; Walter et al., 2006; Abnizova et al., 2012; Laurion et al., 2010). Water bodies are also important because they provide habitats for zooplankton, fish, and migratory birds (Alerstam et al., 2001), and are a source of drinking water for northern communities, of water for irrigation, and of water for industry, exploration, and ice-road construction in winter (Vincent et al., 2013).

Measuring the water temperatures in lakes over both short and long terms is therefore important, not only for modeling the development of the subsurface thermal regime, but also for understanding and modeling ecological and physical dynamics. Few investigations have, however, been carried out into the physical and thermal characteristics of Arctic water bodies, especially over the long term, and there is a partic- ular shortage of data from northern Siberia. A notable exception is the long term biological, physical and chemical lake study initiated in 1975 at the Toolik Lake Long Term Ecological Research (LTER) site in Alaska. The lakes studied are located on the North Slope of Alaska, in the foothills of the Brooks Range, and are classified as low Arctic lakes (Hobbie and Kling, 2014). Toolik Lake and most of the other lakes in this area are "kettle lakes" that formed as a result of glaciation; their lake morphometries (surface areas, depths) are a result of the glaciation history and the age of the landscape. Water depths can range up to $25 \mathrm{~m}$, as is the case in Toolik Lake (Hobbie and Kling, 2014). The thermal stratification varies considerably between lakes (depending on the lake's morphometry), as well as between years (Luecke et al., 2014). Also in northern Alaska, Arp et al. (2010) made use of an original method that combined short-term (for example, over 1 year) measured lake surface temperatures (from depths of 0.5 and $1.0 \mathrm{~m}$ ) with meteorological and remote-sensing data on lake surface temperatures and ice thicknesses. The latter variables were compared with measured temperatures and ice thicknesses, and with modeled results (Arp et al., 2010). The advantage of this approach is that, following successful calibration, a monitoring network can be established that is based purely on remote-sensing data. Monitoring in some of these lakes on the Alaskan Coastal Plain has continued since 2010 as part of the new Circum-Arctic Lakes Observation Network (CALON) initiative (http://www.arcticlakes.org/calon-lakes.html; Hinkel et al., 2012). An initial series of data for vertical temperature profiles from the summer of 2010 has been provided for a number of lakes, together with time series of hourly temperature data, in order to demonstrate the seasonal and temporal variability (Hinkel et al., 2012).

Sporadic measurements of lake temperatures have been obtained in conjunction with limnological studies (for example, by Keatley et al., 2007, or Pienitz et al., 1997), paleolimnological investigations (such as in the $172 \mathrm{~m}$ deep El'gygytgyn Lake of northeastern Siberia, a meteoritic impact crater; Nolan and Brigham-Grette, 2006), and physical experiments (such as dye tracing under the ice cover in a small Arctic lake; Welch and Bergmann, 1985). Vincent et al. (2008) measured temperatures and salinity in a high Arctic, $125 \mathrm{~m}$ deep, perennially ice-covered lake on Ellesmere Island in Nunavut, Canada. The authors then successfully modeled the lake's temperature regime using a onedimensional heat diffusion equation and including heat transfer by radiation through ice and water. For lakes within the Mackenzie Delta (Northwest Territories of Canada), Burn $(2002,2005)$ demonstrated that the temperatures in the deep central pool of a thermokarst lake on Richards Island remained positive throughout the winter, with a mean annual temperature of $3.5^{\circ} \mathrm{C}$, whereas freezing occurred in the shallow littoral terrace of the lake (mean annual temperature $\left.-3.7^{\circ} \mathrm{C}\right)$. 


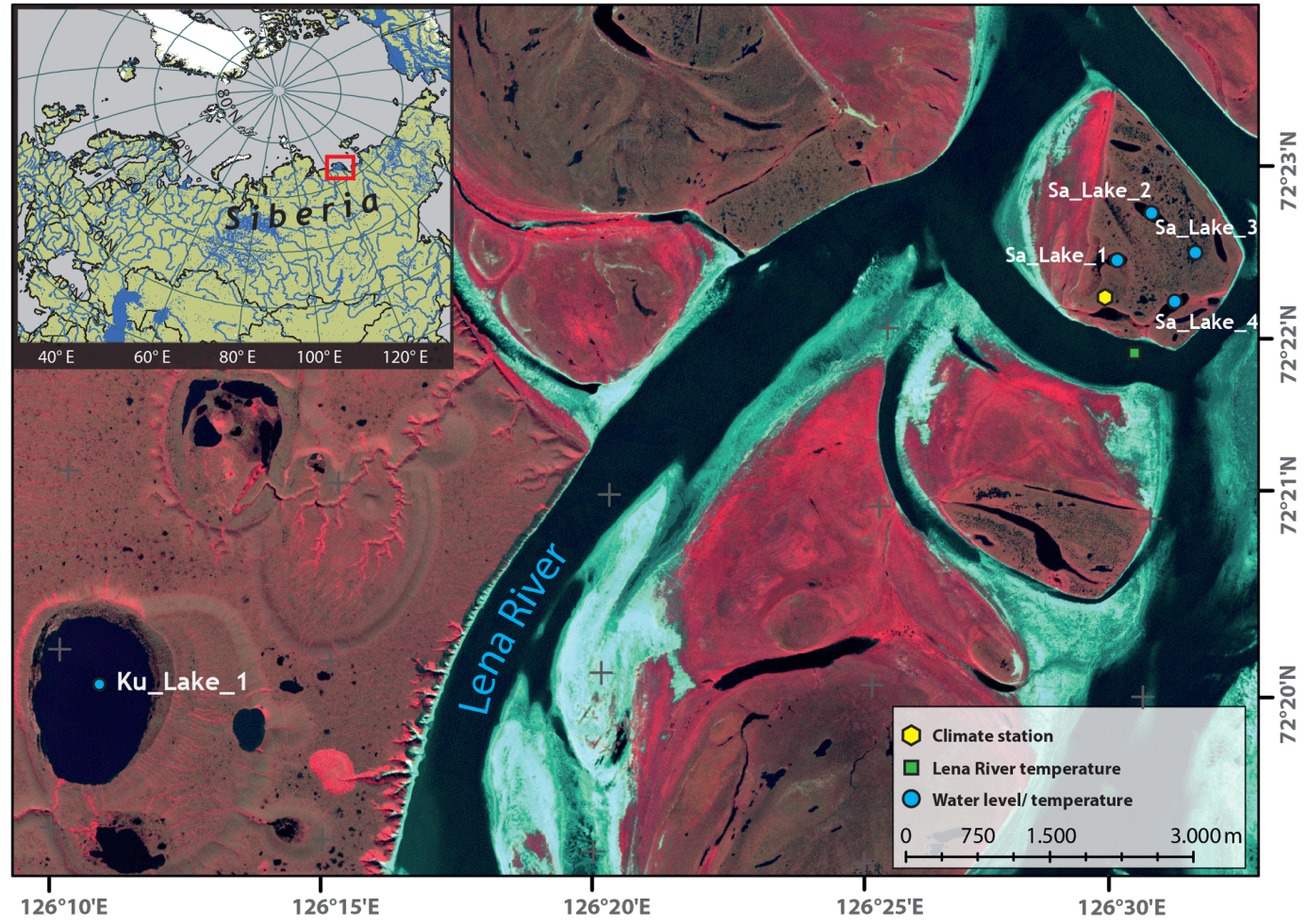

Figure 1. Location of the study sites in the Lena River Delta of eastern Siberia; sites are within the zone of continuous permafrost on the islands of Kurungnakh (Ku_Lake_1), and Samoylov (Sa_Lakes_1-4). The inset map shows the location of the Lena River Delta in northern Eurasia and the distribution of lakes (Global lakes and wetland map; Lehner and Döll, 2004).

This paper aims to quantify the seasonal thermal dynamics of lakes in the Eurasian north, where monitoring observatories have recently been established in the central part of the Lena River Delta. Our objectives are (i) to describe the thermal patterns and processes in both thermokarst lakes and "perched" lakes (which can have seasonal connections to river water), and (ii) to make use of measured data to validate the freshwater model FLake, as well as estimate water sediment heat exchange. FLake offers a good compromise between computational efficiency and physical reality, and has been coupled to several regional and global climate models (Thiery et al., 2014; Martynov et al., 2010). FLake has been used in various one-dimensional modeling studies, for a wide range of lakes, including tropical lakes, and in lake model intercomparison projects (LakeMIP; Thiery et al., 2014; Stepanenko et al., 2010). However, it has not been used for Arctic lakes and this study tests the ability of FLake to reproduce the temperature regimes of thermokarst lakes in northern Siberia.

\section{Site description}

The Lena River Delta in northern Yakutia is one of the largest deltas in the Arctic and has one of the largest catchment areas $\left(2430000 \mathrm{~km}^{2}\right)$ in the whole of Eurasia (Costard and Gautier, 2007). The Lena River discharges about $525 \mathrm{~km}^{3}$ of wa- ter through the delta into the Arctic Ocean every year, with an average annual discharge rate of $16800 \mathrm{~m}^{3} \mathrm{~s}^{-1}$ (Gordeev and Sidorov, 1993). This discharge rate has been reported to be increasing (Fedorova et al., 2015; Rawlins et al., 2009). As it passes through its estuarine area, the main flow of the Lena River splits into numerous arms and transverse branches to form the most extensive delta in the Russian Arctic, covering $25000 \mathrm{~km}^{2}$ and including about 1500 islands and 60000 lakes.

Continuous cold permafrost (with a mean annual temperature of $-10^{\circ} \mathrm{C}$ at $10 \mathrm{~m}$ depth) underlies the study area to between about 400 and $600 \mathrm{~m}$ below the surface. Since observations started in 2006, the permafrost at $10.7 \mathrm{~m}$ depth has warmed by $>1.5^{\circ} \mathrm{C}$ (Boike et al., 2013; http://gtnpdatabase. org/boreholes/view/53/).

The main features of the annual energy balance for these sites with continuous permafrost in the subsurface typically include low net radiation, higher atmospheric latent heat flux than sensible heat flux, and a large proportion of soil heat flux (Boike et al., 2008; Langer et al., 2011a, b). Previous publications have reported that shallow $(<1 \mathrm{~m}$ deep) ponds freeze completely in winter, but that the timing of freezeback can vary by up to 2 months between years, depending on the surface energy balance (Langer et al., 2011b, 2015). 
The study areas are located on the islands of Samoylov and Kurungnakh, within the central part of the Lena River Delta (Fig. 1). Samoylov Island $\left(72^{\circ} 22^{\prime} \mathrm{N}, 126^{\circ} 28^{\prime} \mathrm{E}\right)$ lies within one of the main river channels in the southern part of the delta and is relatively young, with an age of between 4 and $2 \mathrm{ka} \mathrm{BP}$ (Schwamborn et al., 2002), which is also the estimated maximum age of the investigated lakes on the island. In contrast, Kurungnakh Island forms part of the third terrace of the Lena Delta and is an erosional remnant of a latePleistocene accumulation plain. It consists of fluvial sands overlain by Yedoma-type ice complex deposits, which accumulated between 100 and $50 \mathrm{kaBP}$ and since $50 \mathrm{kaBP}$, respectively, and a Holocene cover (8 to $3 \mathrm{ka} \mathrm{BP}$ ) (Schwamborn et al., 2002; Wetterich et al., 2008). Large thermokarst lakes and basins are major components of the ice-rich permafrost landscape of Kurungnakh Island; they have formed since 13 to $12 \mathrm{ka} \mathrm{BP}$ (Morgenstern et al., 2011, 2013).

The lakes presented in this paper are of thermokarst origin which is common for the lowland tundra permafrost areas of Northeast Siberia. These areas were not ice-covered during the latest glacial period (70000-10000 years ago) and are characterized by high to moderate ground ice content and thick sediment cover. Arctic lowlands with similar landscape characteristics and lake distributions can be found in central and eastern Siberia, interior and northern Alaska as well as northwest Canada (Grosse et al., 2013).

The landscape on both of these islands, and in the delta as a whole, has generally been shaped by water through erosion and sedimentation (Fedorova et al., 2015), and by thermokarst processes (Morgenstern et al., 2013). The proportion of the total land surface of the delta covered by surface water can amount to more than $25 \%$ (Muster et al., 2012). Up to $50 \%$ of the total surface water area in permafrost landscapes is attributed to small lakes and ponds with surface areas of less than $10^{5} \mathrm{~m}^{2}$, which have the potential to grow into large thermokarst lakes (Muster et al., 2012). Water budget modeling for the tundra landscape has shown a small positive balance since 1953, which has been confirmed by satellite observations (since 1964) of the surface areas of water bodies (Boike et al., 2013). The chemical and isotopic signals from the water in lakes on Samoylov Island generally indicate low levels of mineralization (Table 1). The stable isotopic ratios indicate that the thermokarst lake water is sourced mainly from thawed ground ice mixed with precipitation and the water in shallow ponds is sourced mainly from summer precipitation (Abnizova et al., 2012).

Small ponds and lakes emit more $\mathrm{CO}_{2}$ and $\mathrm{CH}_{4}$ per square meter than the surrounding tundra, and greenhouse gas production continues during winter in those lakes that do not freeze to the bottom (Langer et al., 2015). Modeling studies have demonstrated that an unfrozen layer of lake sediment is maintained throughout the year beneath thermokarst lakes (Yi et al., 2014). During high spring floods some of the lakes on the first terrace are flooded with Lena River water. Observations in 2014 on Samoylov Island, for example, confirmed the flooding of a large part of the first terrace on the island, including most of the lakes.

Additional detailed information concerning the climate, permafrost, land cover, vegetation, and soil characteristics of these islands in the Lena River Delta can be found in Boike et al. (2013) and Morgenstern et al. (2013).

\section{Methods}

\subsection{Field instrumentation and ground surveys}

In July 2009, water level and temperature sensors (HOBO Temp Pro v2, HOBO U20, Onset, $\pm 0.2^{\circ} \mathrm{C}$ across a temperature range from 0 to $70^{\circ} \mathrm{C}$, and $\pm 0.4^{\circ} \mathrm{C}$ across a temperature range from -40 to $0^{\circ} \mathrm{C}$ ) were installed within the water columns of the investigated lakes on Samoylov and Kurungnakh islands. Figure 1 shows the locations of the lakes (labelled Sa_Lake_1-4 for Samoylov and $\mathrm{Ku} \_$Lake_1 for $\mathrm{Ku}-$ rungnakh) and the location of the long-term weather station. Gaps in the climate data record (air temperature, radiation, humidity, wind speed and direction, and snow depth) were filled whenever possible with data from temporary climate and eddy covariance stations located in close proximity to the weather station (Boike et al., 2013). Temperature and water depth sensors were placed directly above the sediment-water interface and then temperature sensors at $2 \mathrm{~m}$ intervals up to $2 \mathrm{~m}$ below the water surface (Fig. 2). The sensors were suspended in the water column from a buoy and anchored in the sediment below. The sensor at the bottom of the lake (just above the sediment) was labelled as " $0 \mathrm{~m}$ ", the sensor $2 \mathrm{~m}$ above the sediment as " $2 \mathrm{~m}$ ", and so on. The uppermost sensors were usually about $2 \mathrm{~m}$ below the water surface since we were concerned about the formation of ice and the potential drift of sensors with the shifting of ice cover. End-ofwinter ice thickness (obtained by drilling) was measured in 2014; it ranged between 1.9 and $2 \mathrm{~m}$ in lakes Sa_Lake_14 on Samoylov Island. During some winters the uppermost sensors became enclosed within the ice cover (for example, Sa_Lake_1 in 2012), but they were not moved out of position. One sensor was installed in the Lena River during August 2009 (Fig. 1) and recorded data from July 2009 to August 2010 but was lost during the following year.

Sensors were usually retrieved once a year (in August) and then re-launched in approximately the same position. The temperature record was therefore briefly interrupted during the period when the sensors were retrieved and read. The water depth ("sensor depth") recorded by the bottom sensor sometimes changed following retrieval due to a change in the sensor position, although the actual water level of the lake remained the same. For example, for Sa_Lake_4 (a perched lake), sensors that were deployed at a water depth of about $8.5 \mathrm{~m}$ in 2009 were reinstalled at a depth of about $9.5 \mathrm{~m}$ in August 2010. Water level variations due to water balance changes (when the sensor position had not changed), 
Table 1. Physical and chemical characteristics of the studied lakes in the Lena River Delta, Siberia.

\begin{tabular}{|c|c|c|c|c|c|}
\hline & Sa_Lake_1 & Sa_Lake_2 & Sa_Lake_3 & Sa_Lake_4 & Ku_Lake_1 \\
\hline Area $\left[\mathrm{m}^{2}\right]$ & 39541 & 39991 & 23066 & 47620 & $1730000^{\mathrm{a}}$ \\
\hline Max. depth [m] & 6.4 & 5.7 & 3.4 & 11.6 & $3.6^{\mathrm{a}}$ \\
\hline Mean depth [m] & 3 & 3.1 & 1.2 & 4.5 & 2.4 \\
\hline Volume $\left[\mathrm{m}^{3}\right]$ & 106500 & 103600 & 18800 & 175121 & 3321000 \\
\hline Volume/Area [m] & 2.7 & 2.6 & 0.8 & 3.7 & 1.8 \\
\hline Perimeter $[\mathrm{m}]$ & 1931 & 1471 & 1760 & 1474 & $5170^{\mathrm{a}}$ \\
\hline Period of data collection & $4 \mathrm{Jul} 2009$ to & $10 \mathrm{Jul} 2009$ to & $13 \mathrm{Jul} 2009$ to & $6 \mathrm{Jul} 2009$ to & $24 \mathrm{Jul} 2009$ to \\
\hline & 7 Aug 2012 & 7 Aug 2012 & 14 Aug 2012 & 6 Aug 2012 & $29 \mathrm{Jul} 2010$ \\
\hline Location & $\begin{array}{l}126.486^{\circ} \mathrm{E} \\
72.373^{\circ} \mathrm{N}\end{array}$ & $\begin{array}{l}126.496^{\circ} \mathrm{E} \\
72.378^{\circ} \mathrm{N}\end{array}$ & $\begin{array}{l}126.511^{\circ} \mathrm{E} \\
72.374^{\circ} \mathrm{N}\end{array}$ & $\begin{array}{l}126.505^{\circ} \mathrm{E} \\
72.369^{\circ} \mathrm{N}\end{array}$ & $\begin{array}{l}126.177^{\circ} \mathrm{E} \\
72.328^{\circ} \mathrm{N}\end{array}$ \\
\hline Start of ice cover formation & 5 Oct 2009 & 1 Oct 2009 & 4 Oct 2009 & 4 Oct 2009 & 4 Oct 2009 \\
\hline (temp. diff. from bottom to top & 1 Oct 2010 & 28 Sep 2010 & 30 Sep 2010 & 28 Sep 2010 & 2 Oct 2010 \\
\hline$\left.>0.1^{\circ} \mathrm{C}\right)$ & 2 Oct 2011 & 5 Oct 2011 & 26 Sep 2011 & 4 Oct 2011 & \\
\hline Start of ice cover break-up & 4 Jul 2009 & 12 Jul 2009 & 24 Jun 2009 & 7 Jul 2009 & 24 Jul 2009 \\
\hline (temp. diff. from bottom to top & 14 Jun 2010 & 23 Jun 2010 & 14 Jun 2010 & 20 Jun 2010 & 20 Jun 2010 \\
\hline$\left.>0.1^{\circ} \mathrm{C}\right)$ & 8 Jun 2011 & 16 Jun 2011 & 10 Jun 2011 & 20 Jun 2011 & \\
\hline & 15 Jun 2012 & 15 Jun 2012 & 10 Jun 2012 & 21 Jun 2012 & \\
\hline$\%$ ice cover (satellite radar & 5 Jun $100 \%$ & 5 Jun $100 \%$ & 5 Jun $100 \%$ & 5 Jun $95 \%$ & 5 Jun $95 \%$ \\
\hline data $\left.^{\mathrm{b}}\right)$ & 10 Jun $95 \%$ & 10 Jun $100 \%$ & 10 Jun $90 \%$ & 10 Jun $95 \%$ & 10 Jun $95 \%$ \\
\hline 2011 & 16 Jun $85 \%$ & 16 Jun $90 \%$ & 16 Jun ice free & 16 Jun $85 \%$ & 16 Jun $90 \%$ \\
\hline & 21 Jun ice free & 21 Jun ice free & & 21 Jun $50 \%$ & $\begin{array}{l}21 \text { Jun } 40 \% \\
27 \text { Jun ice free }\end{array}$ \\
\hline 2012 & 27 Jun ice free & 27 Jun ice free & 27 Jun ice free & 27 Jun ice free & $\begin{array}{l}5 \text { Jun } 90 \% \\
27 \text { Jun ice free }\end{array}$ \\
\hline $\begin{array}{l}\text { Mean annual bottom } \\
\text { temperature }\left[{ }^{\circ} \mathrm{C}\right] \\
(2010-2011)\end{array}$ & 3.7 & 3.6 & 2.7 & 2.9 & 4.0 \\
\hline $\begin{array}{l}\text { Winter lake water heat budget } \\
{\left[\mathrm{MJ} \mathrm{m}^{-2}\right]}\end{array}$ & 93 & 66 & 44 & 145 & 61 \\
\hline $\begin{array}{l}\text { Summer lake water heat budget } \\
{\left[\mathrm{MJ} \mathrm{m}^{-2}\right]}\end{array}$ & 140 & 206 & 161 & 340 & 112 \\
\hline Annual lake heat budget & [233] & {$[272]$} & [205] & [485] & {$[173]$} \\
\hline $\begin{array}{l}{\left[\mathrm{MJ} \mathrm{m}^{-2}\right]} \\
(2010-2011)^{\mathrm{c}, \mathrm{d}}\end{array}$ & 838 & 877 & 810 & 1090 & 778 \\
\hline Residence time [years] ${ }^{\mathrm{e}}$ & 14 & 14 & 4 & 24 & 9 \\
\hline $\begin{array}{l}\text { Electrical conductivity } \\
{\left[\mu \mathrm{S} \mathrm{cm}^{-1}\right]}\end{array}$ & $140^{\mathrm{f}}$ & $127^{\mathrm{f}}$ & $64^{\mathrm{i}}$ & $185^{\mathrm{f}}$ & $30^{\mathrm{i}}$ \\
\hline pH-value ${ }^{f}$ & $6.99^{\mathrm{f}}$ & $6.82^{\mathrm{f}}$ & 7. $3^{\mathrm{i}}$ & $\begin{array}{l}80^{\mathrm{h}} \\
6.95^{\mathrm{f}} \\
7.36^{\mathrm{g}} \\
7.28^{\mathrm{h}}\end{array}$ & $7.64^{\mathrm{i}}$ \\
\hline
\end{tabular}

${ }^{\text {a }}$ Data provided in Morgenstern et al. $(2011,2013)$ and doi:10.1594/PANGAEA.848485. ${ }^{\mathrm{b}}$ Sobiech et al. (2012) \& TerraSar-X data (copyright: DLR, 2011) where available with sufficiently high resolution. ${ }^{\mathrm{c}}$ Numbers in brackets represent the total annual lake water budget (sensible heat), without taking into account the latent heat of ice cover formation. ${ }^{\mathrm{d}}$ Includes latent heat for the formation of a $2 \mathrm{~m}$ ice cover (605 $\mathrm{MJ} \mathrm{m}^{-2}$ ).

brackets represent the total annual lake water budget (sensible heat), without taking into account the latent heat of ice cover formation. ${ }^{\mathrm{d}}$ Includes latent heat for the formation of a $2 \mathrm{~m}$ ice cover ( $\left.605 \mathrm{MJ} \mathrm{m}{ }^{-2}\right)$.
${ }^{\mathrm{C}}$ Residence time $F=V / E$; roughly approximated by the ratio of the lakes's volume $(V)$ divided by the sum of evapotranspiration $(E)$ and runoff $R(F=V /(E-R) ;$ Schertzer, 1997$)$. Within the study area, the annual e Residence time $F=V / E$; roughly approximated by the ratio of the lakes's volume $(V)$ divided by the sum of evapotranspiration $(E)$ and runoff $R(F=V /(E-R)$; Schertzer, 1997). Within the study area, the annual
evapotranspiration is about $\sim 190 \mathrm{~mm}$ and runoff is to be negligible within the overall water balance (Boike et al., 2013). ${ }^{\mathrm{f}}$ Mean value for ice-covered period (April-May 2014). ${ }^{\mathrm{g}}$ Mean value for the Lena River flood period (May-June 2014). ${ }^{\mathrm{h}}$ Mean value for summer period (July-August 2014). ${ }^{\mathrm{i}}$ Mean value for summer period (measured in July 2009).

for example during the summer period, were usually less than $0.5 \mathrm{~m}$.

Data are only available over a 1-year period for the lake on Kurungnakh Island (2009-2010) as the loggers were subsequently displaced, presumably during ice break-up. For the lakes on Samoylov Island, however, we obtained continuous temperature and water level data over a period of 3 years from 2009 to 2012. All data and metadata are provided in the Supplement for this publication and through the PANGAEA website (doi:10.1594/PANGAEA.846525).

Bathymetric surveys were carried out in 2009 and 2010 on all of the investigated thermokarst lakes, using a GPSMAP 178 Cecho sounder, a GPSMAP 421S plotter and a GPS 60 navigator, all from Garmin. The shorelines were mapped either by GPS field survey or by manually digitizing the shoreline from high-resolution aerial images. The accuracy of the echo sounder equipment was about $0.1 \mathrm{~m}$ and was regularly checked using manual profiling. Depth measurements were taken along the longest lake axis as well as along a zigzag track in order to cover most of the lake surface and to locate any local "holes" that might exist as a result of thermokarst processes. Surface areas, mean and maximum depths, volumes, and hypsographic (depth/area) curves were calculated for the five lakes investigated using linear distance nearest neighbor interpolation in ArcGIS software (v.10.1) (Table 1). A description of the morphometry, including two-dimensional contour plots and cross-sectional profiles of the lakes can be found in the appendix of this paper (Figs. A1 to A5). Bathymetric records were also obtained for eight additional lakes (Chetverova et al., 2013) but are not included herein since temperature sensors were not installed. Bathymetric data, metadata and morphomet- 


\section{Water Surface}

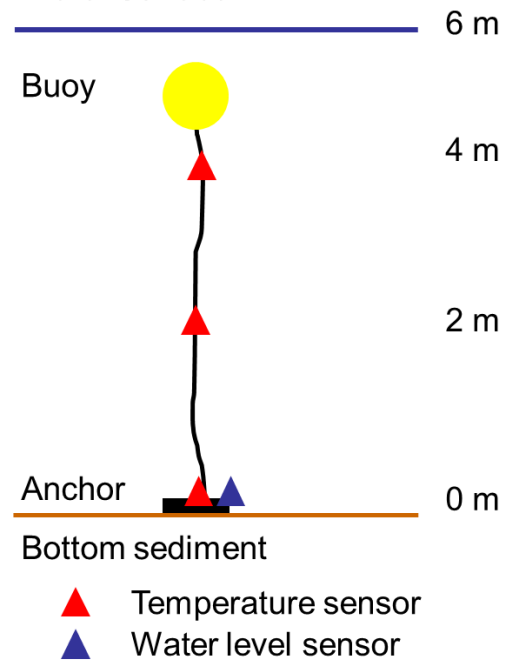

Figure 2. Schematic diagram showing the positions of sensors within the water column. To prevent freezing of the buoy within the ice cover (maximum $2 \mathrm{~m}$ thick), sensors were deployed $2 \mathrm{~m}$ below the water surface in most lakes. The water level sensor was located just above the bottom sensor, referred to in Figs. 4 and 5 as the "lowest sensor depth".

ric descriptions can be found in the appendix material for this publication, as well as through the PANGAEA website (doi:10.1594/PANGAEA.846525).

\subsection{Heat content}

The ability of lakes to store and redistribute additional heat at seasonal timescales may affect the heat budget of adjacent permafrost areas at the landscape spatial scale. For this reason, we observe the thermal regime of tundra lakes to make inferences about their effect on heat exchange processes. The heat content of each lake $\left(H_{1}\right)$ was calculated at hourly time steps from the thermal energy stored in a water column from the lake's surface to its maximum depth $\left(z_{\max }\right)$ :

$H_{1}=c_{\mathrm{w}} \rho_{\mathrm{w}} \int T(z, t) \mathrm{d} z$,

where $c_{\mathrm{w}}$ is the specific heat capacity of water, $\rho_{\mathrm{w}}$ is the freshwater density, and $T$ is the temperature. The calculated heat budgets were divided into different time periods, as proposed by Wetzel (2001). The summer heat income is defined as the amount of heat required to raise the temperature of the lake from isothermal conditions at $4{ }^{\circ} \mathrm{C}$ to the maximum observed depth-averaged summer temperature (summer heat content). The winter heat income is the amount of heat required to raise the temperature from the minimum temperatures to $4{ }^{\circ} \mathrm{C}$. The annual heat budget is the total amount of heat necessary to raise the water from the minimum temperature to maximum summer temperature. The winter heat income and the annual heat budget must include the latent heat of fusion for the ice cover, especially for high-latitude lakes (Wetzel, 2001). The ice cover thickness was measured during May 2014 and varied slightly from $2 \mathrm{~m}$ (Sa_Lake_1, Sa_Lake_2) to $1.9 \mathrm{~m}$ (Sa_Lake_4). The ice cover in these lakes melts completely every summer so that freezing and melting energies usually balance out over a year. The timing of spring ice break-up extends from the first ice melt, through moat formation and drifting of the ice cover, to the complete disappearance of ice. It is defined herein as the time at which the temperatures from all sensors indicate isothermal conditions, with temperature differences from the bottom to the top of the water column of $<0.1^{\circ} \mathrm{C}$ following the period of stratification that occurs during ice cover, i.e., the time at which the lake water becomes completely mixed. The ice formation in fall is defined by the start of stratification in lake temperatures, i.e., when temperature differences from bottom to top exceed $0.1^{\circ} \mathrm{C}$. The uncertainties in these determined times are estimated to be \pm 5 days and are based on comparison with (infrequently available) satellite data (Table 1).

\subsection{Modeling of lake thermodynamics}

FLake is a freshwater lake model (Mironov, 2008) aimed at predicting the vertical thermal structure and mixing conditions in lakes over periods ranging from a few hours to a few years. The model is based on a two-layer parametric representation of the evolving temperature profile in the water column and on the integrated heat and kinetic energy budgets. The upper mixed layer is treated as thermally homogeneous, while the structure of the stratified layer between the upper mixed layer and the bottom of the basin (the lake thermocline) is described using the concept of self-similarity (or assumed shape) of the temperature-depth curve. The same selfsimilarity concept is used to describe the temperature structure of the thermally active upper layer of bottom sediments (Golosov and Kirillin, 2010) and of the ice (Mironov et al., 2012). It should be noted that no change in water depth as a result of winter ice formation is included in the computation, and the water depth is therefore assumed to be constant. Precipitation is also not included as an input into the model and snow accumulation is therefore not computed. Visual observations confirm that the lakes are usually snow free due to the generally low snowfall (although a few areas with snow and hardened wind crusts occur locally), combined with high wind speeds blowing the snow away.

The following input data and settings were used for the lakes investigated in this study and tested with data for Sa_Lake_1, i.e., a lake depth of $4 \mathrm{~m}(93 \%$ of this lake has a water depth of not more than $4 \mathrm{~m}$ ), a water optical light extinction coefficient of $0.5 \mathrm{~m}^{-1}$, a $6 \mathrm{~m}$ thickness for the thermally active sediment layer beneath the lake, and a temperature of $4.5^{\circ} \mathrm{C}$ at the bottom of the thermally active sediment layer. Due to their very low contents of organic material and low levels of biological productivity the lakes are usually very clear: in shallow lakes (for example, Sa_Lake_3) the 


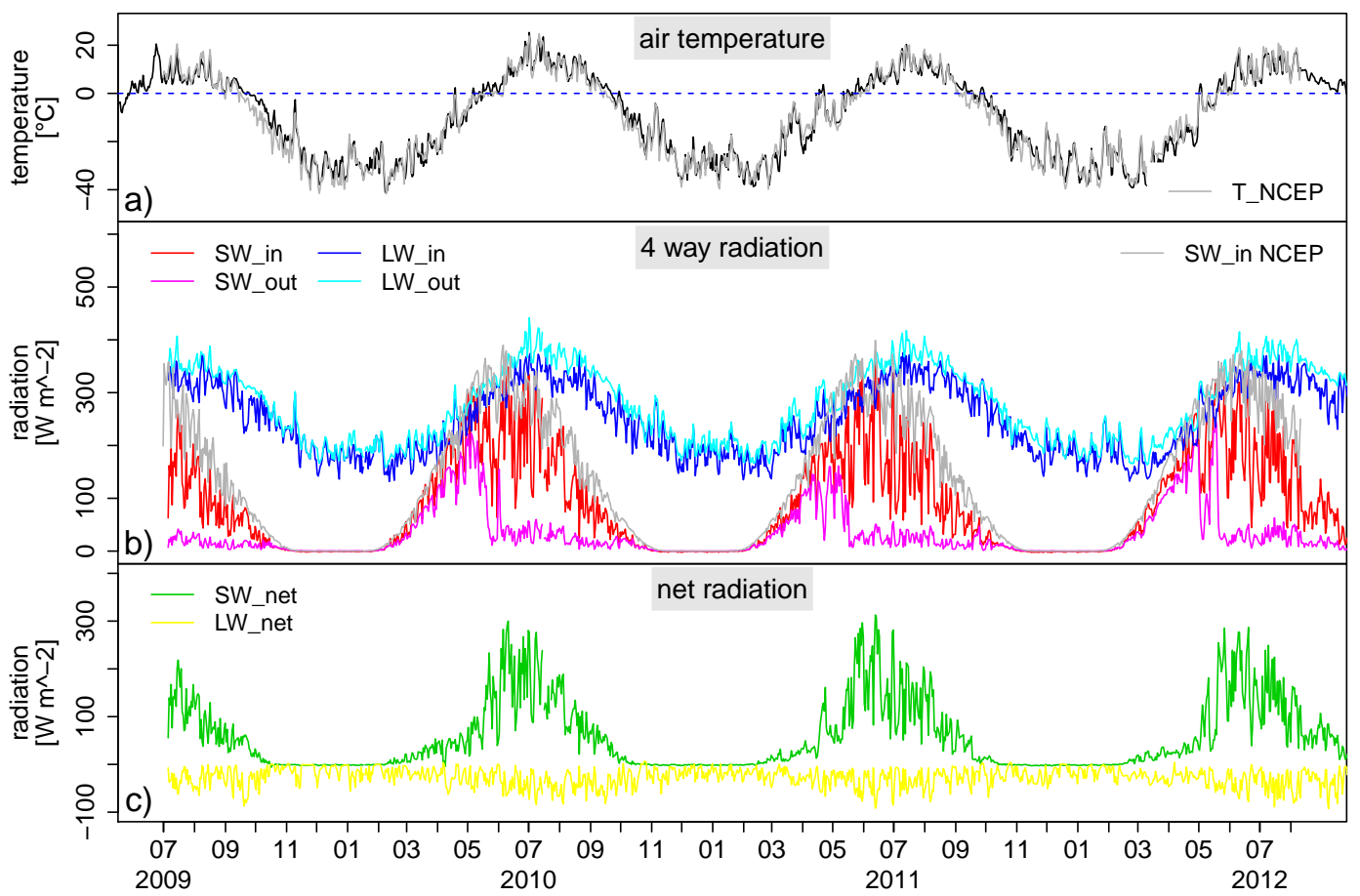

Figure 3. (a) Mean daily air temperature at $2 \mathrm{~m}$ above ground level from Samoylov and NCEP; (b) radiation balance (Samoylov) and shortwave incoming radiation (NCEP); (c) net shortwave and longwave radiation (Samoylov) and radiation balance measured at the Samoylov climate station July 2009 to August 2012.

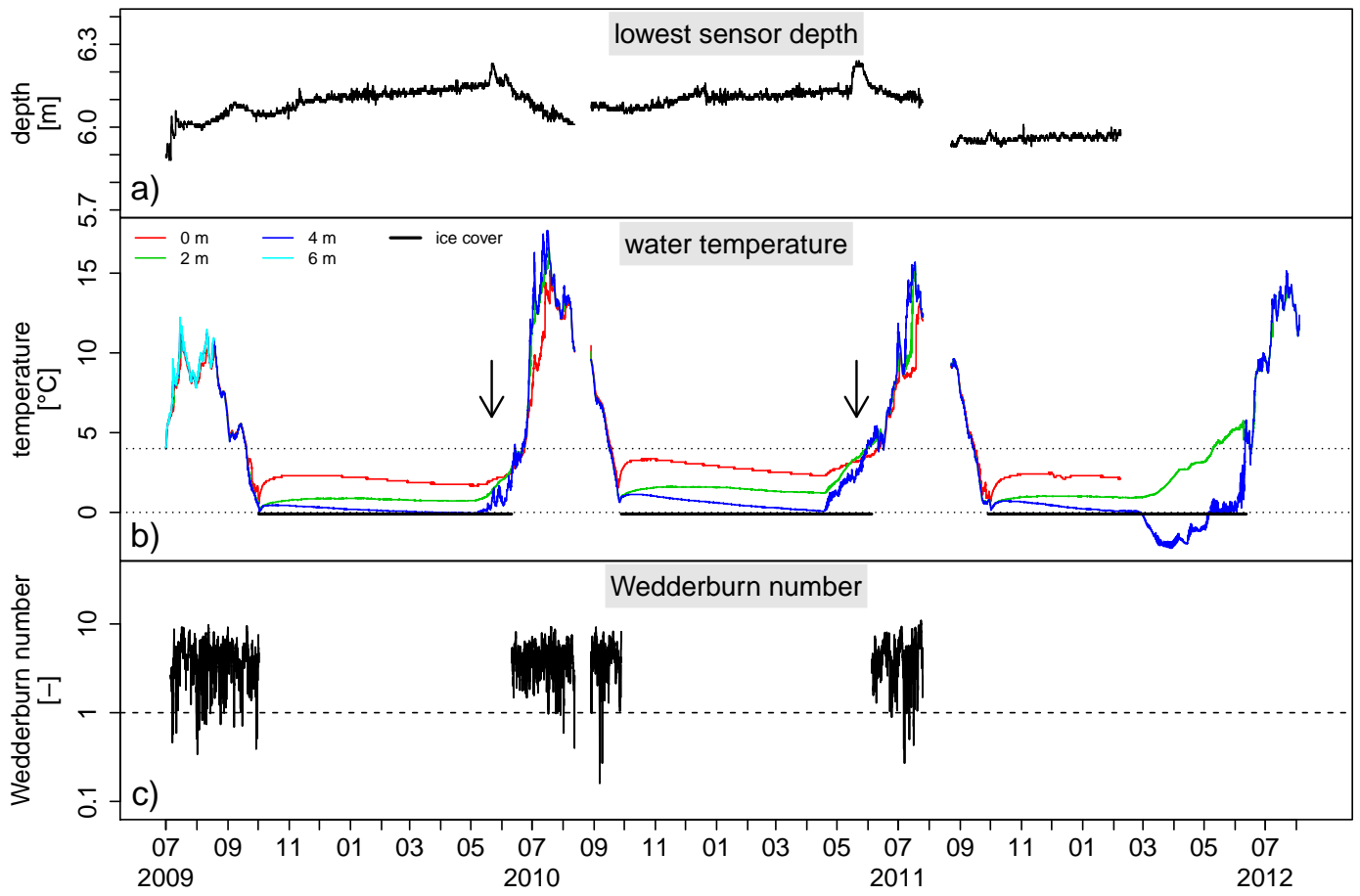

Figure 4. Hourly physical characteristics for Sa_Lake_1, July 2009 to August 2012. (a) Depth of bottom lake sensor as an indicator of water level changes; (b) water temperatures and ice cover duration; (c) Wedderburn number (dimensionless), calculated for the ice-free period only. Arrows indicate the timing of the lake's seasonal flooding by Lena river water. 


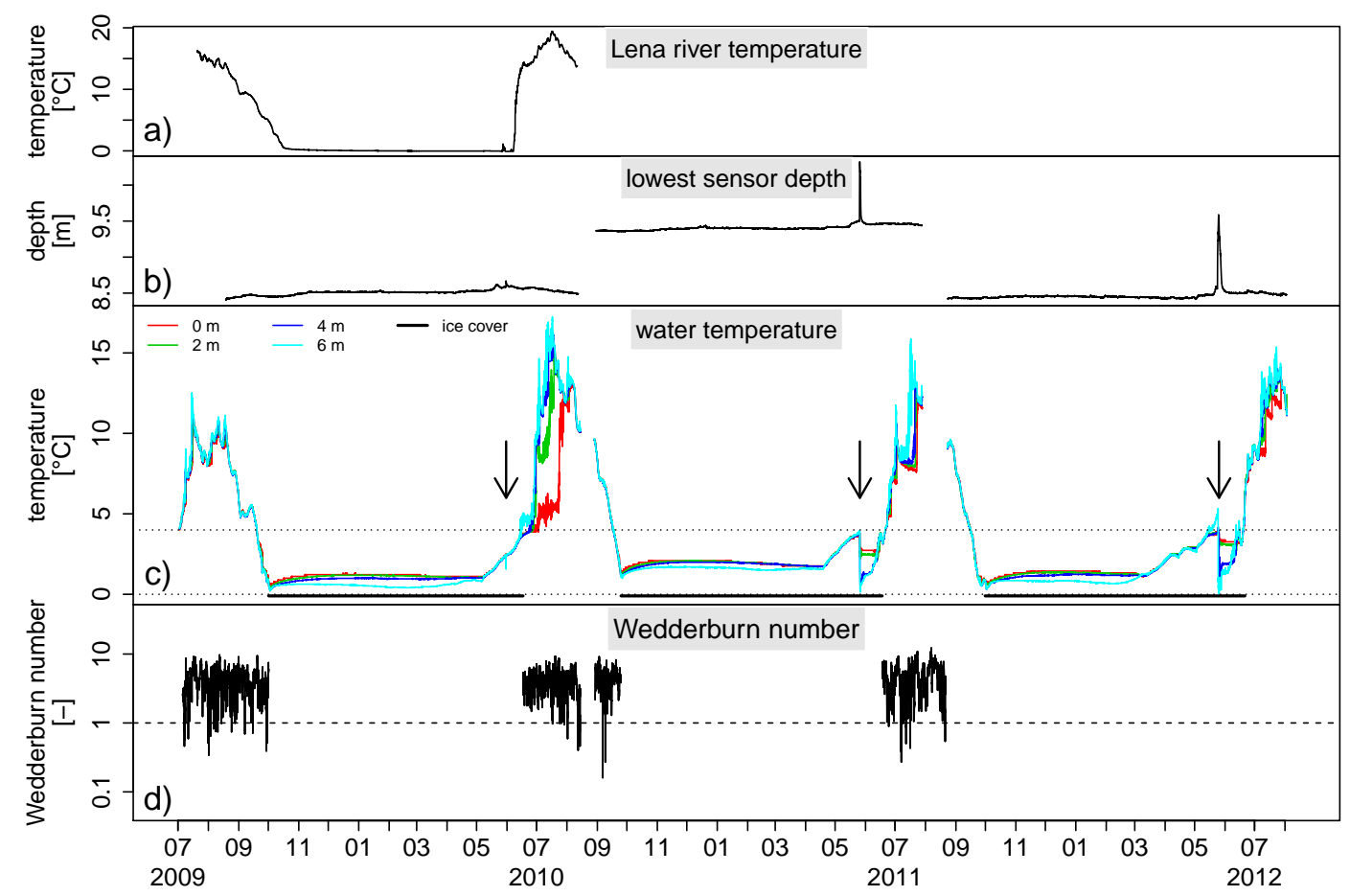

Figure 5. (a) Hourly temperatures for the Lena River from July 2009 to July 2010, and for Sa_Lake_4 (July 2009-August 2012): (b) depth of bottom sensor as indicator for water level changes: sharp increase in depth during May 2011 and 2012 indicates flooding with Lena River water; (c) water temperatures and ice cover duration; (d) Wedderburn number (dimensionless) calculated for the ice-free period. Arrows indicate the timing of the lake's seasonal flooding by Lena river water.

lake bottom is visible even at $2 \mathrm{~m}$ water depths. The thermal characteristics of the sediment are based on sediment temperatures measured beneath two lakes in the Lena River Delta (on the Bykovsky Peninsula; Grigoriev, 1993) and are discussed in Sects. 4 and 5. Two temperature profiles were obtained in June 1984 for one shallow $(1 \mathrm{~m})$ and one deep $(5 \mathrm{~m})$ lake, down to a sediment depth of 16 and $21 \mathrm{~m}$ below the lake bed, respectively. These temperature profiles are used as input for the model experiments since the assumption of thermal equilibrium does not necessarily exist for the lakes in the permafrost landscape.

Two meteorological data sets were used to drive the model: (1) hourly data from the on-site weather station (air temperature at $2 \mathrm{~m}$ height, wind speed, humidity, and radiation components), and (2) 6-hourly NCEP/NCAR reanalysis data provided by the NOAA/OAR/ESRL PSD, Boulder, Colorado, USA (http://www.esrl.noaa.gov/psd/; Kalnay et al., 1996). The two driving data sets were compared and were found to be in good agreement with each other, having some discrepancies in the short-wave radiation components (Fig. 3). The modeled lake temperatures were nearly identical in both data sets (not shown), indicating that reanalysis data sets perform well for lake modeling in these remote areas, where on-site meteorological information is often limited. For further analysis we used the measured on-site meteorological data set, which can be found in the Supplement for this publication. The FLake model output parameters (water temperatures, ice cover thickness, bottom sediment heat flux) for one of the lakes (Sa_Lake_1) are compared for the time period 9 July 2009 to 29 July 2011 with the measured parameters in Sect. 4. The model was used to:

- validate the one-dimensional modeling approach and qualify the main mechanisms governing features of the lake thermal regime, such as summer stratification, water-sediment heat exchange, and ice melt,

- characterize the water-sediment heat exchange at annual timescales,

- establish a relationship between the morphometry and summer stratification duration.

The "Lake Analyzer" numerical tool (http://lakeanalyzer. gleon.org/; Read et al., 2011) was used to determine the dimensionless Wedderburn number $(W d)$, a quantitative measure of the balance between wind mixing and stratification that is important for describing the biogeochemical cycles of lakes (Spigel and Imberger, 1980). A $W d$ number of 1 indicates a threshold value at which the wind shear brings the thermocline to the lake's surface along the upwind shoreline. For large Wedderburn numbers $(\gg 1)$ the buoyancy force is much greater than the wind stress suggesting strong vertical stratification. For small Wedderburn numbers $(\ll 1)$ the wind 
stress is much greater than the buoyancy force suggesting destruction of the vertical thermal stratification in the lake. Onsite weather data from hourly time series of water temperature, wind speed, and bathymetric data were used as model inputs for the calculation of $W d$.

\section{Results}

\subsection{Lake thermal dynamics based on observations}

The following analyses were based on temperature and sensor depth (water depth) data collected over the course of 3 years (2009-2012) from the investigated lakes, covering a range of morphometric characteristics and located on two geomorphologically different terraces (consisting of sediments of the Pleistocene Ice Complex on Kurungnakh and a Holocene flood plain on Samoylov). The seasonal thermal dynamics are only discussed in detail for two of these lakes: Sa_Lake_1 which is a thermokarst lake, and Sa_Lake_4 which is a perched/oxbow lake (Figs. 4 and 5; an animation of the daily temperatures of Sa_Lake_1 is also provided in the Supplement). These lakes were selected as they have the best data records, taking into account the temporal coverage and the total number of sensors in each lake profile. The seasonal temperature dynamics of the other lakes (Sa_Lake_2, Sa_Lake_3, and Ku_Lake_1) are illustrated in the Appendix of this paper (Figs. A6-A8).

\subsection{Fall and winter}

During fall, cooling and complete mixing occurs at about the end of September resulting in isothermal conditions at $0^{\circ} \mathrm{C}$ immediately prior to ice cover formation (Figs. 4 and 5 ). The ice cover growth can be briefly interrupted due to short-lived warming events during the fall (as was observed, for example, in late September and early October of 2008) but the ice cover then persists from October through to June (Figs. $4 \mathrm{~b}$ and $5 \mathrm{c}$; Table 1). The water column becomes stratified following the formation of the ice cover and the initial isothermal conditions change so that lake-bottom temperatures are consistently warmer than those higher up in the water column (towards the water/ice interface). This bottom temperature development under ice, which involves rapid warming immediately after ice-cover formation followed by subsequent gradual cooling, takes place in all lakes but the rates of warming and cooling vary (Figs. 4b, 5c, A6-A8). In Sa_Lake_1 the maximum vertical temperature gradient was less than $1^{\circ} \mathrm{Cm}^{-1}$ (with a maximum of $1^{\circ} \mathrm{C} \mathrm{m}^{-1}$ ) in the winter of 2010/2011 and decreased over the course of the winter (Fig. 4b). In Sa_Lake_4, the maximum temperature gradient was less than $0.2^{\circ} \mathrm{C} \mathrm{m}^{-1}$ and, in contrast, increased over the course of the winter (Fig. 5c). The waters in both lakes remained stratified during the winter, with gradual overall cooling of the stratified profile continuing until the end of winter.

\subsection{Spring}

The snow cover on the tundra landscape was usually very thin during the winter $(<0.5 \mathrm{~m})$ and had usually thawed by the end of May or early June. Field observations during a number of spring field campaigns showed that the frozen surfaces of the lakes were normally kept snow-free by wind action. It is interesting to note that the under-ice warming of the water column (Figs. 4b, 5c) started as early as the beginning of March (e.g., in 2012), when air temperatures were still well below $0{ }^{\circ} \mathrm{C}$, as a result of strong solar radiation input through the ice. A temperature increase of about $4{ }^{\circ} \mathrm{C}$ over the 6-week period prior to ice break-up is equal to an energy input of about $30 \mathrm{~W} \mathrm{~m}^{-2}$. With solar radiation returning after the polar night, the shortwave net radiation on the ice surface is about $50 \mathrm{~W} \mathrm{~m}^{-2}$ in March and increases to about $300 \mathrm{~W} \mathrm{~m}^{-2}$ by the end of May or the beginning of June (Fig. 3b). The net shortwave radiation penetrating to the water column is thus reduced by about $15-20 \%$ as a result of transmission through the ice cover. Radiation can penetrate to great water depths depending on the optical properties of the lake water. Assuming light extinction in the water column to be $0.5 \mathrm{~m}^{-1}$, about $13 \%$ of the radiation penetrating the ice cover (or $\sim 4 \mathrm{~W} \mathrm{~m}^{-2}$ ) will reach the lake floor beneath $4 \mathrm{~m}$ of water. The solar radiative heating of the water (still below its maximum density at $4{ }^{\circ} \mathrm{C}$ ) and subsequent convective mixing effectively reduced the temperature gradient beneath the ice cover to less than $0.5^{\circ} \mathrm{Cm}^{-1}$ for Sa_Lake_1 and less than $0.1^{\circ} \mathrm{C} \mathrm{m}^{-1}$ for Sa_Lake_4 (Figs. $4 \mathrm{~b}$ and $5 \mathrm{c}$ ), this being a well-known mechanism in ice-covered fresh water lakes during spring (Mironov et al., 2002; Kirillin et al., 2012). Continued solar radiation and air temperature warming induce lake ice melt, which can also be accelerated by high wind speeds. For example, in 2009 the ice cover on Sa_Lake_1 was observed to drift, break-up, shrink, and then disappear, over the course of just a few days due to strong, warm winds. Satellite radar observations from 2011 show that the ice cover break-up occurred over a period of about 10 days from the beginning of June, starting with the formation of a moat. On 10 June all lakes had an ice cover with a moat (i.e., an unfrozen ring close to the shoreline); on 21 June, Sa_Lakes 1, 2, and 3 were ice free but the largest and deepest lakes (Ku_Lake_1 and Sa_Lake_4) still had 40$50 \%$ ice cover (Table 1). Complete mixing of the water, as indicated by the first isothermal conditions after the winter stratification (Table 1), had already occurred during the early part of ice break-up (Table 1; Figs. 4b, 5c). The lakes were usually ice free by the middle or end of June (Table 1).

Seasonal flooding by the Lena River was an additional process that had an important effect on the water temperatures in Sa_Lake_4 (which was formed in a former river channel) and Sa_Lake_1. River ice break-up and flooding took place at the end of May in all 3 years, when the lakes were still ice covered (Table 1). Lena River temperatures recorded over a complete year (2009-2010) showed that the river tempera- 
tures remained around $0{ }^{\circ} \mathrm{C}$ during the winter, warmed up briefly for about 2 days to a peak temperature of $1.1^{\circ} \mathrm{C}(31$ May 2010) and then cooled again to $0^{\circ} \mathrm{C}$ before steadily increasing thereafter to reach a maximum of $19.4{ }^{\circ} \mathrm{C}$ on 20 July 2010 (Fig. 5a). Radiative under-ice warming and convection in Sa_Lake_4 continued until lake ice break-up in 2010, but this spring under-ice warming was interrupted in both 2011 and 2012 by intense flooding with cold Lena River water, as indicated by both the temperature profiles and the water depth data (Fig. 5b). The water level in this lake rose by about $1 \mathrm{~m}$ over the course of a few hours (28-29 May 2011 and 2728 May 2012), returning to the original level within 4-5 days. Concomitant with water level rise in Sa_Lake_4, the water temperatures fell to $0^{\circ} \mathrm{C}$ in the upper sensors (immediately beneath the ice). Lake_Sa_1 was also connected to the river during the flood events, as can be recognized by the slight increase in water depth at the end of May in 2010 and 2011 (no water depth data are available for 2012), but the increase was less than in Sa_Lake_4 (<10 cm variation; Fig. 4a).

\subsection{Summer}

During the summer months positive air temperatures and continuous heat input from solar radiation steadily raised the water temperatures of the lakes at all depths, until September. Heat input from net shortwave radiation supplied about $150 \mathrm{~W} \mathrm{~m}^{-2}$ in mid-July (Fig. 3). Maximum air temperatures occurred over very short (daytime) periods, reaching up to more than $25^{\circ} \mathrm{C}$. The highest air temperatures were recorded in July 2010 , reaching a maximum of $31.9^{\circ} \mathrm{C}$ on 5 July.

All of the lakes experienced short periods of thermal stratification during the summer, which varied both between the lakes and between the summers; the highest temperature gradient reached was about $5^{\circ} \mathrm{Cm}^{-1}$ in the deepest lake, Sa_Lake_4 (Fig. 5). Maximum water temperatures of around $20^{\circ} \mathrm{C}$ were usually reached in mid-July, with up to $22^{\circ} \mathrm{C}$ recorded for the shallow lake (Sa_Lake_3). Mean monthly bottom temperatures during periods with no ice cover ranged between 4 and $15^{\circ} \mathrm{C}$ (Fig. 6), and can therefore be considerably higher during the summer than their annual means (Table 1).

The monthly bottom temperatures for some lakes were also warmer than the corresponding monthly air temperatures (Fig. 6), confirming that radiation input is an important additional energy source, as well as effective mixing of the lake waters. Starting with colder mean bottom temperature in July, gradual warming creates warmest mean bottom temperatures in the deepest lake (Sa_Lake_4) in August and in the shallowest lake (Sa_Lake_3) in July. For all other lakes, maximum bottom temperatures occur either in July or August, depending on the timing of ice break up and the lake's seasonal energy balance.

The Wedderburn numbers are in agreement with the observed short periods of weak stratification during the icefree period (Figs. 4c, 5d). Remarkably, $W d$ remain rather

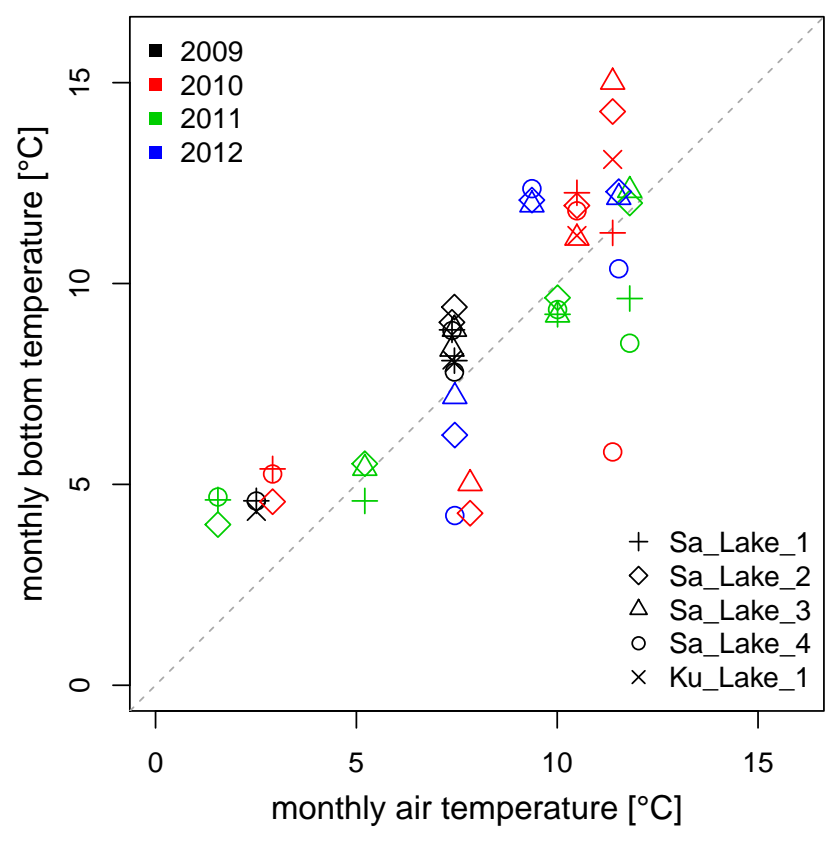

Figure 6. Relationship between mean monthly lake bottom temperatures for all five lakes during the ice-free period and the corresponding mean monthly air temperatures, from July 2009 to August 2012. Data are also provided in the Supplement of this paper.

low throughout the whole summer (between 1 and 8 for Sa_Lake_1 and Sa_Lake_4) and there are even short periods with $W d<1$. These $W d$ values indicate that buoyancy and wind stress were almost in equilibrium, suggesting favorable conditions for occasional upwelling of the thermocline along the upwind shorelines of the lakes, which would make an additional contribution to the mixing of water in the lakes and to the heat-mass exchange between the lakes and the atmosphere. During short periods with $W d<1$ the wind stress is much greater than the buoyancy, effectively destroying the thermal stratification.

\subsection{Lake heat content}

The heat content in the investigated lakes at times varied by up to $\pm 50 \mathrm{MJ} \mathrm{m}^{-2}$ over just a few days (Fig. 7), with the maximum heat content being reached at the end of July or in early August. The summer heat income of the lakes was of the order of 100 to $400 \mathrm{MJ} \mathrm{m}^{-2}$ and had a linear relationship with their depths (see Eq. 1). The winter heat income of the lake water beneath the ice cover varied between 50 and $150 \mathrm{MJ} \mathrm{m}^{-2}$, not including the heat transfer associated with the formation of the ice cover. However, if a $2 \mathrm{~m}$ thick ice cover is taken into account (which is especially important for Arctic lakes; Wetzel, 2001), the annual heat budget can reach up to about $1 \mathrm{GJ} \mathrm{m}^{-2}$ (Table 1).

Sa_Lake_4, which can be subjected to substantial seasonal flooding during spring, showed a reduction in heat content of about $100 \mathrm{MJ} \mathrm{m}^{-2}$ (in 2010 and 2011) within a few hours, 


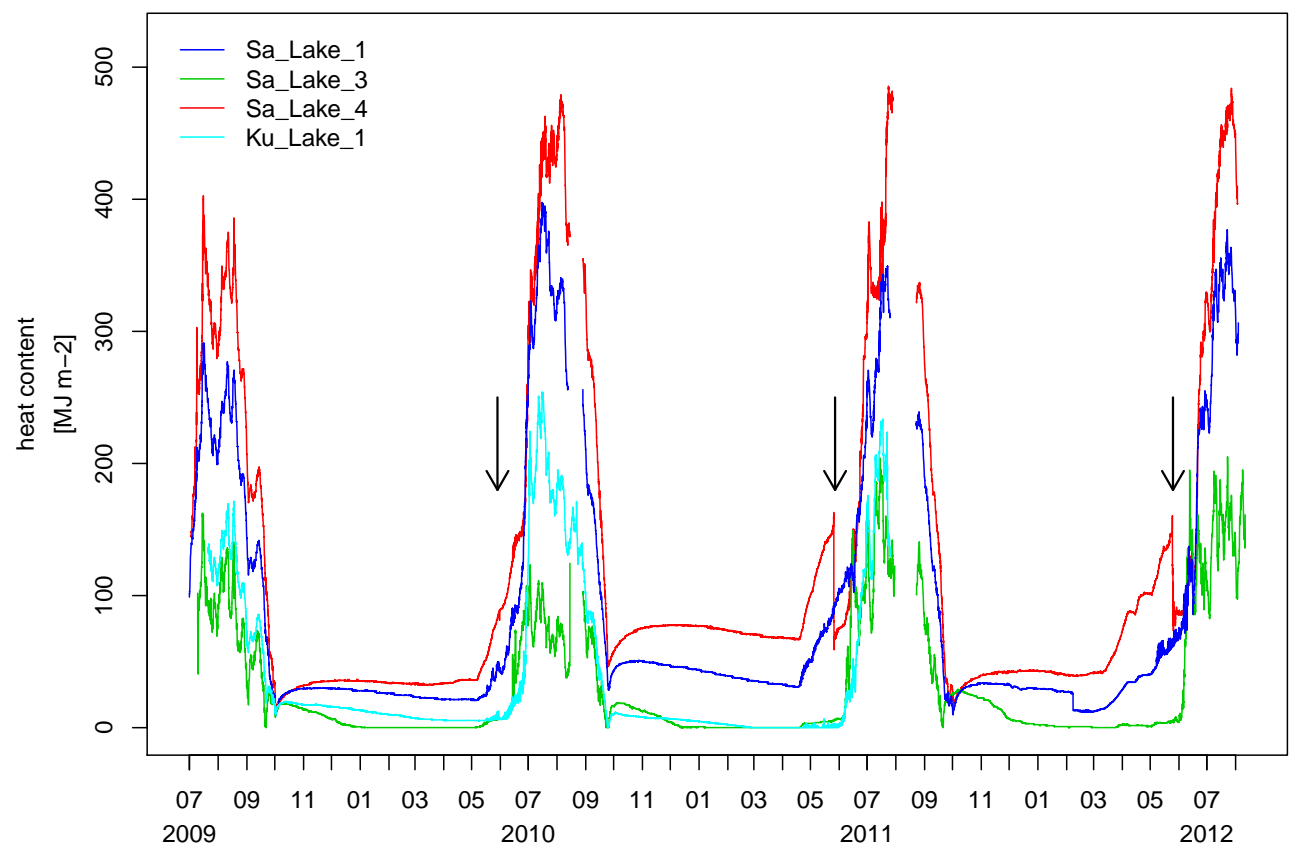

Figure 7. Sensible heat content (calculated using Eq. 1) for four lakes lakes, from July 2009 to August 2012. Arrows indicate the timing of the lake's seasonal flooding by Lena river water.

thus suppressing the ongoing radiative warming of the lake water. Although the Lena River carries a substantial amount of heat into its delta every year $\left(\sim 0.49 \times 10^{12} \mathrm{~J} \mathrm{~s}^{-1}\right.$; Alekseevsky, 2007) due to very warm summer temperatures, the flooding of the lakes occurs when its temperatures are at their coldest.

\subsection{Modeled seasonal lake thermal dynamics}

A comparative analysis of the modeling results and observational data has revealed the capabilities of, and flaws in, the use of one-dimensional modeling to reproduce the thermal dynamics of lakes formed on permafrost, as well as providing additional quantitative insights into the major mechanisms governing the seasonal thermal dynamics of Siberian lakes. The FLake model results for the Sa_Lake_1 over a period of 2 years (2009-2011) have been in overall good agreement with on-site observations with regard to seasonal variations in lake temperatures, the mean and maximum temperatures in winter and summer, and the durations of the open water and ice cover seasons (Fig. 8a-c).

To quantify the model performance for thermokarst lakes we applied standard measures (e.g., Thiery et al., 2014) of the model's ability to reproduce the observed mean temperature $\left(T_{\mathrm{m}}\right)$, the standard deviation ratio $\left(\mathrm{SD}_{\text {model }} / \mathrm{SD}_{\mathrm{obs}}\right)$, the centered root mean squared error $\left(\mathrm{RMSE}_{\mathrm{c}}\right)$, and the Pearson correlation coefficient $(r)$. In contrast to other lake model evaluations using surface temperature $T_{\mathrm{S}}$ (for example, from African and west European lakes), we used $T_{\mathrm{m}}$ since no temperature probes were installed at the surface due to the seasonal ice cover. FLake demonstrated good performance with regard to the mean lake temperature. The statisticsPearson correlation coefficient $r=0.97, \mathrm{SD}_{\text {model }} / \mathrm{SD}_{\text {obs }}$ $1.28, \mathrm{RMSE}_{\mathrm{c}} 1.49^{\circ} \mathrm{C}$ are slightly worse than those reported previously for temperate lakes ( $r=0.988$; Stepanenko et al., 2010) and better than FLake performance on deep tropical lakes $\left(r=0.78, \mathrm{SD}_{\text {model }} / \mathrm{SD}_{\text {obs }} 1.25, \mathrm{RMSE}_{\mathrm{c}} 0.75^{\circ} \mathrm{C}\right.$; Thiery et al., 2014). The model reproduced summer stratification during the ice-free period $\left(r=0.93, \mathrm{SD}_{\text {model }} / \mathrm{SD}_{\text {obs }}\right.$ $\left.1.25, \mathrm{RMSE}_{\mathrm{c}} 1.82^{\circ} \mathrm{C}\right)$. Solar heating of the water below the ice is not included in the model and thus the agreement between model and observations is lower during the icecovered period $\left(r=-0.42, \mathrm{SD}_{\text {model }} / \mathrm{SD}_{\text {obs }} 0.37, \mathrm{RMSE}_{\mathrm{c}}\right.$ $0.66^{\circ} \mathrm{C}$ ). The resulting uncertainties in the ice break up prediction affect also the model performance with regard to the lake heat content at the beginning of the open water period in early summer (Fig. 8). As thermal dynamics under the ice cover are crudely reproduced by the majority of onedimensional lake models used in coupled climate modeling systems (Stepanenko et al., 2010), estimation of the role played by thermokarst lakes in regional climate requires integration of a cost-effective and physically sound sub-model of winter lake thermodynamics into lake parameterization schemes for climate models (e.g., Oveisy and Boegman, 2014).

\subsubsection{Open water period and summer stratification}

The duration of the warming and cooling periods, as well as the mean water temperatures during the autumn cooling, 


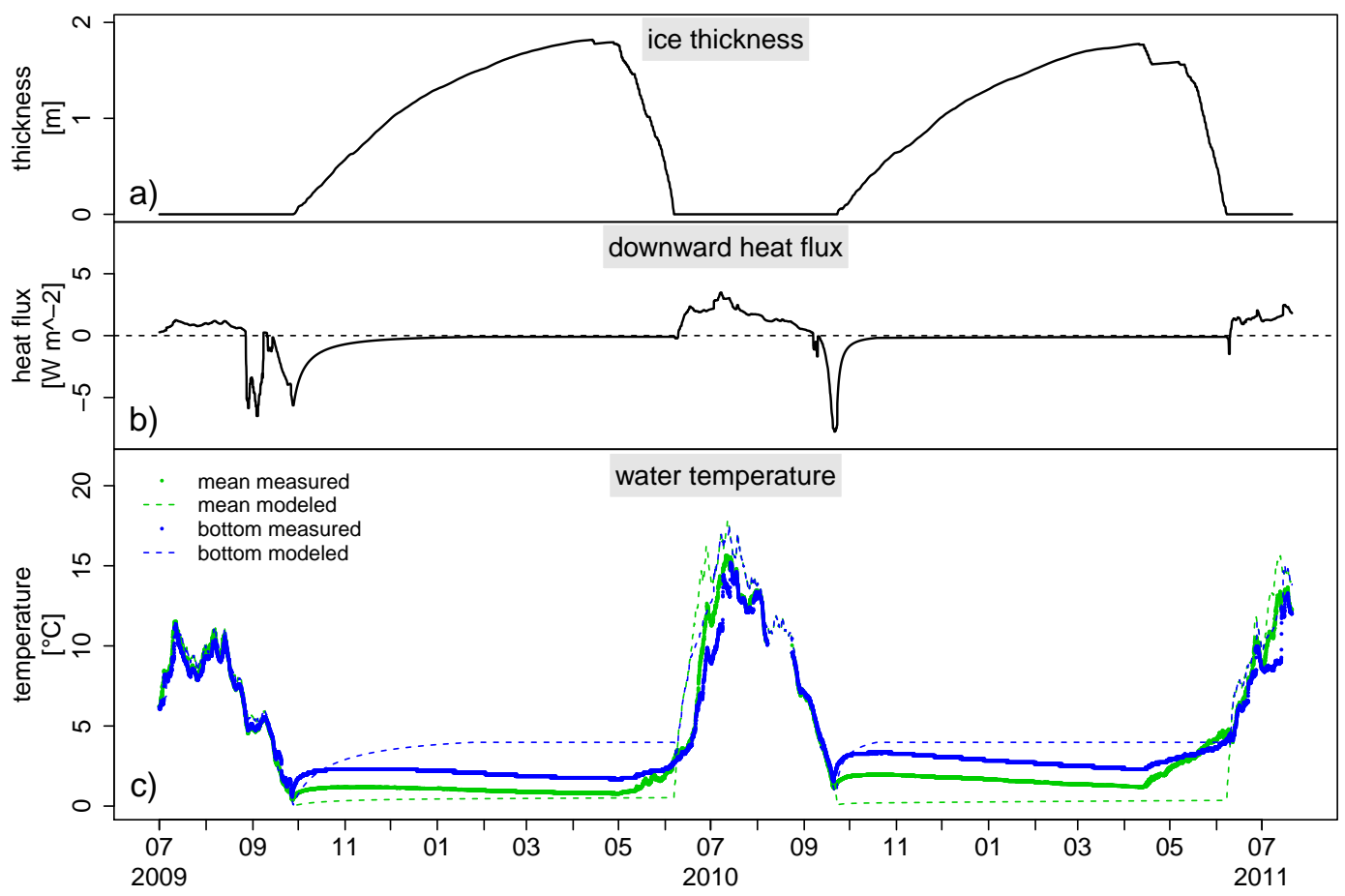

Figure 8. Modeled and measured hourly characteristics for Sa_Lake_1 from August 2009 to August 2011. (a) Modeled ice thickness; (b) modeled vertical heat flux at the water-sediment boundary: negative fluxes indicate fluxes from the sediment into the water column - a running median filter was used to remove spikes; (c) measured (continuous line) and modeled (dashed lines) lake-bottom and mean water temperatures.

are well simulated by the model suggesting that the model adequately captures the net heat storage of the lakes. The model was also able to reproduce the development of weak thermal stratification in summer (i.e., the short periods during which the bottom temperatures differed from the mean temperatures of the lakes in June and July, 2010 and 2011: Fig. 8c). The largest discrepancies in the water temperatures produced by the model occurred during the period of spring warming, with maximum deviations of about $6^{\circ} \mathrm{C}$ from the measured mean temperatures (Fig. 8). These deviations can be explained by the ice break-up being modeled too early, with subsequent early warming of the lake. Lake temperatures were consequently consistently overestimated during the warming period in 2010 .

\subsubsection{Ice duration and thickness, and water temperatures beneath the ice cover}

The mean rate of ice growth modeled with FLake was about $0.92 \mathrm{~cm} \mathrm{day}^{-1}$ for 2010 (minimum $0.021 \mathrm{~cm} \mathrm{day}^{-1}$, maximum $8 \mathrm{~cm} \mathrm{day}^{-1}$ ) and $0.89 \mathrm{~cm} \mathrm{day}^{-1}$ for 2011 (minimum $0.026 \mathrm{~cm} \mathrm{day}^{-1}$, maximum $4.6 \mathrm{~cm} \mathrm{day}^{-1}$ ), with the maximum thickness of ice cover remaining below $2 \mathrm{~m}$. The modeled ice thickness of no more than $2 \mathrm{~m}$ agrees well with the temperature data from the sensor located $4 \mathrm{~m}$ above the sediment (approximately $2 \mathrm{~m}$ from the lake surface) in
Sa_Lake_1 (Fig. 4b). This sensor did not record any freezing in 2010 or 2011, but in 2012 the sensor froze into the lake ice (Fig. 4b), recording sub-zero temperatures and thus indicating thicker ice (>2 m) in 2012.

The modeled melting of the ice cover in spring and subsequent warming of lake temperatures is, in general, well reproduced by the model. The measured development of underice bottom temperatures (with warming following the onset of ice cover formation, followed by a later winter cooling) is only partly reproduced in the modeled results due to rather simplified parameterization of the under-ice thermodynamics in the FLake model, with a linear vertical temperature profile in the ice-covered water column and no solar radiation penetrating the ice cover.

\subsubsection{Thermal properties of the lake sediments and water-sediment heat flux}

Heat conduction from a lake's water column to the underlying sediment is a key thermodynamic process for understanding the role of lakes in the permafrost landscape. The Flake model incorporates simulation of seasonal temperature variations within the thermally active sediment layer, based on an assumption of thermal equilibrium in the sediment over longer-than-seasonal timescales (i.e., a constant temperature beneath the seasonally thermally active sediment layer, 
ensuring zero mean annual flux across the water-sediment boundary; Golosov and Kirillin, 2010). Since this thermal equilibrium does not necessarily exist in lakes on permafrost, we performed two separate model experiments with different thermal conditions beneath the lakes, based on temperature profiles measured in lake sediments at comparable sites in the Lena River Delta (Grigoriev, 1993; Fig. 9). While the sediment temperature beneath the shallow lake fell to below $0{ }^{\circ} \mathrm{C}$ at about $2 \mathrm{~m}$ depth and reached $-6{ }^{\circ} \mathrm{C}$ at $15 \mathrm{~m}$ depth, the temperatures beneath the deeper lake indicated an unfrozen layer to about $25 \mathrm{~m}$ depth, with a maximum temperature of about $4.5^{\circ} \mathrm{C}$ at a depth of about $3 \mathrm{~m}$ beneath the lake floor (Fig. 9a, b). The reported temperatures at depth, where seasonal variations were minimal, ranged from $-6^{\circ} \mathrm{C}$ beneath the $1 \mathrm{~m}$ deep lake to $4^{\circ} \mathrm{C}$ beneath the $5 \mathrm{~m}$ deep lake. Using the measured temperature profile below the $5 \mathrm{~m}$ deep lake, the thickness of the sediment layer with appreciable seasonal variations in temperature was estimated to be $\sim 6 \mathrm{~m}$ (Fig. 9 b). The FLake modeled heat flux at the lake-sediment boundary for different ground temperatures revealed two characteristic seasonal patterns of lake-permafrost heat exchange: the flux across the frozen sediment beneath the shallow lake was directed downwards during the summer, with a magnitude of up to $4 \mathrm{~W} \mathrm{~m}^{-2}$, the fast release of heat from the sediment during autumn cooling, and the water-sediment heat flux of $\sim 0 \mathrm{~W} \mathrm{~m}^{-2}$ during the entire ice-covered period (Fig. 9c). This seasonal pattern suggests an annually positive heat budget of the under-lake ground and thawing of the permafrost, which is continuously heated by the lake above. For a lake with deep sediment temperatures approaching $4{ }^{\circ} \mathrm{C}$, the annual mean flux across the sediment tended towards zero, with maximum downward fluxes in summer of $3 \mathrm{~W} \mathrm{~m}^{-2}$, a maximum of $7 \mathrm{~W} \mathrm{~m}^{-2}$ heat released back into the water column during early freeze back, and a continuous low rate of $<1 \mathrm{~W} \mathrm{~m}^{-2}$ during the ice-covered winter (Fig. 9d). In the absence of any additional information available on the ground temperatures under Sa_Lake_1, the latter case was adopted for the longer model run (Fig. 8b, c), with an "equilibrium state" suggesting little or no permafrost thawing beneath the lake. The maximum modeled heat flux at the sediment-water interface was about $4 \mathrm{~W} \mathrm{~m}^{-2}$ into the sediment (in summer) and about $7 \mathrm{~W} \mathrm{~m}^{-2}$ (to almost zero) from the sediment into the water column during the ice-covered period. The rapidly changing (negative) hourly heat fluxes during the fall cooling period were due to rapid cooling of the water column, which could not be reproduced by the model.

Overall, the calculated energy density for the lake with mean annual water temperature of $3{ }^{\circ} \mathrm{C}$ is about $65 \mathrm{MJ} \mathrm{m}^{-3}$, thus more than six times the amount for the permafrost soil of about $10 \mathrm{MJ} \mathrm{m}^{-3}$. Lakes are therefore effective for energy storage compared to the frozen landscape, and the fraction of landscape covered by thermokarst lakes has the potential to significantly affect the land-atmosphere energy exchange.

\section{Discussion}

Lakes can be considered to represent "hot spots" in the permafrost landscape. This study has demonstrated that the investigated lakes remain unfrozen throughout the winter and have mean bottom water temperatures (between 2.7 to $4.0^{\circ} \mathrm{C}$ ) that are significantly warmer than the mean annual air temperature $\left(\sim-13^{\circ} \mathrm{C}\right)$ or the permafrost temperature $\left(-9.2^{\circ} \mathrm{C}\right.$ at $10.7 \mathrm{~m}$ depth). This is in agreement with observations made by Jorgenson et al. (2010) who reported thermokarst lake-bottom temperatures in Alaska that were up to $10^{\circ} \mathrm{C}$ warmer than the mean annual air temperatures. Harris (2002) attributed the anomalously high mean annual temperature in a shallow lake in western Canada to convective heat exchange and the absorption of radiation through the water column. Mean annual lake-bottom temperatures in northern Alaska also showed a similar range of values (Arp et al., 2012; CALON), and this range has therefore been used in previous modeling studies to estimate the development of talik (Burn, 2002; Ling and Zhang, 2003). Differences in heat content are related to morphometric parameters, particularly to water depth. Burn (2002) found mean annual lake-bottom temperatures of between 1.5 and $4.8^{\circ} \mathrm{C}$ for the deeper pools in tundra lakes on Richards Island (northwestern Canada). Ensom et al. (2012) reported mean annual bottom temperatures of between 3.4 and $5.5^{\circ} \mathrm{C}$ from a number of lakes and channels in the Mackenzie Delta (Canada) and computed that $60 \%$ of the lakes maintained taliks.

Mean bottom lake temperatures, which ranged between 2.7 and $4{ }^{\circ} \mathrm{C}$ in this study, depend on lake depth and are important for constraining future numerical modeling experiments on talik development. Our study also confirms previous findings that there is a "critical lake depth" (lake depth > winter ice cover thickness) for water to remain unfrozen beneath the ice cover (Arp et al., 2012; Burn, 2002). All lakes in this study had a depth $>3 \mathrm{~m}$, which exceeds the maximum ice thickness of about $2 \mathrm{~m}$.

The bottom temperatures in the lakes varied significantly between summer and winter but their annual mean temperatures and temperature dynamics were similar despite the range of morphometric and geomorphological characteristics. The $W d$ numbers indicated that the lakes were all wellmixed during the summer periods, and it can therefore be assumed that both heat and dissolved gases, in particular, oxygen, are effectively transported through the water column. This assumption is supported by the measured oxygen concentrations in these lakes, which ranged between 8 and $10 \mathrm{mg} \mathrm{L}^{-1}$, and the lack of any detected vertical stratification (R. Osudar, personal communication, 2015).

We observed and simulated short stratification periods in summer in the studied lakes (Figs. 4 and 5). These stratification events are probably the major physical factor affecting biogeochemical processes in lakes. In particular, the duration of the thermal stratification in summer affects the concentration and vertical distribution of dissolved oxygen. 

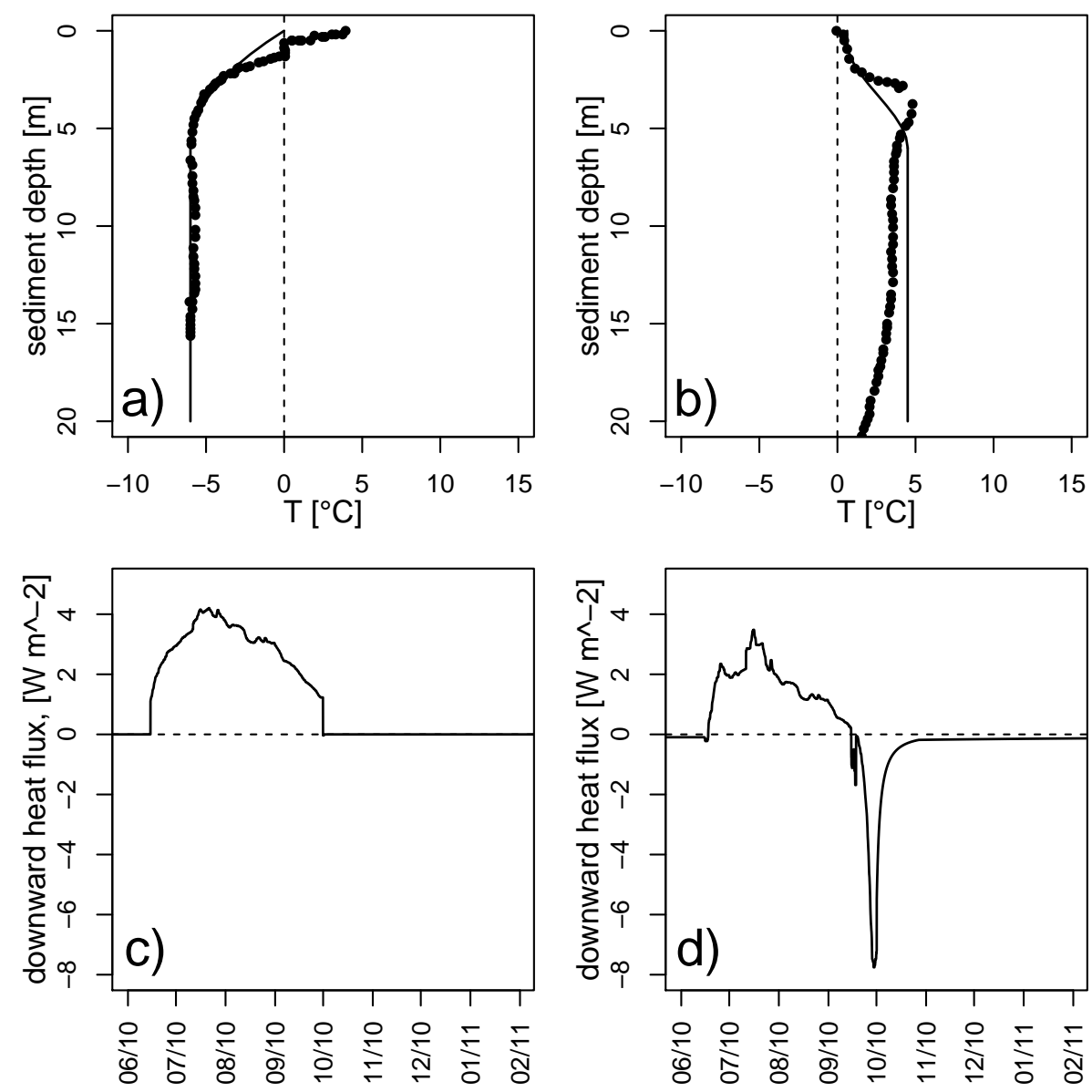

Figure 9. (a, b) Measured temperature profiles (squares) beneath two lakes (with a) $1 \mathrm{~m}$ water depth, and (b) $5 \mathrm{~m}$ water depth) on the Bykovsky Peninsula, in the southeastern part of the Lena River Delta (Grigoriev, 1993). Temperatures were measured between 9 and 11 June 1984. Modeled sediment temperature profiles (continuous line) are for 10 June 2010 using model parameters described in the Methods section. (c, d) Modeled daily vertical heat flux at the water-sediment boundary for (c) the shallow lake, and (d) the deep lake, $2010-2011$.

Longer summer stratification provokes deep anoxia and favors methanogenesis in the deep water column and upper sediment (Golosov et al., 2012). Under equal climatic forcing, lake depth is the primary factor determining the duration of summer stratification (the second one being the water transparency, Kirillin, 2010). Sensitivity model runs with the lake depth varying in the range $2-12 \mathrm{~m}$ using the same meteorological input data from Samoylov demonstrated that lakes in this climatic zone with mean depths $>5 \mathrm{~m}$ should have dimictic stratification regimes, i.e., develop continuous stratification in summer with a duration of 1 month or longer (Fig. 10). This also supports the observation of summer stratification in deeper $(>6 \mathrm{~m})$ Alaskan thermokarst lakes (Sepulveda-Jáuregui et al., 2015). In lakes of about $8 \mathrm{~m}$ depth or more, the summer stratification duration significantly increases since high thermal inertia prevents vertical mixing during the autumn cooling in August-September (Fig. 11).

The summer heat budgets of Arctic lakes are much smaller than those of low-latitude lakes. The only previously re- ported summer heat budget for an Arctic lake (Chandler Lake, Alaska) was $240 \mathrm{MJ} \mathrm{m}^{-2}$, which lies in the same range as the heat budgets in this study (Wetzel, 2001). In contrast, the summer heat budget for a large lake such as Lake Superior on the Canada-USA border is much larger at about $1.3 \mathrm{GJ} \mathrm{m}^{-2}$. In comparison, the annual heat budget of Lake Baikal in Siberia is estimated to be about $2.7 \mathrm{GJ} \mathrm{m}^{-2}$ (Wetzel, 2001). The total annual heat budget for all of the investigated lakes (including the latent heat of the ice cover) amounts up to about $1 \mathrm{GJ} \mathrm{m}^{-2}$ (Table 1). In view of the large proportion of land covered by water bodies in this landscape $(25 \%)$ and the volumes of water that they contain, their energy storage and turnover within the permafrost landscape are of considerable significance. Furthermore, changes in the heat content of lakes occur much more rapidly than changes in the heat content of the surrounding permafrost soils as a result of efficient energy absorption and effective mixing. In contrast, progressive deepening of the seasonally thawing upper layer of permafrost (the active layer) of the polygo- 


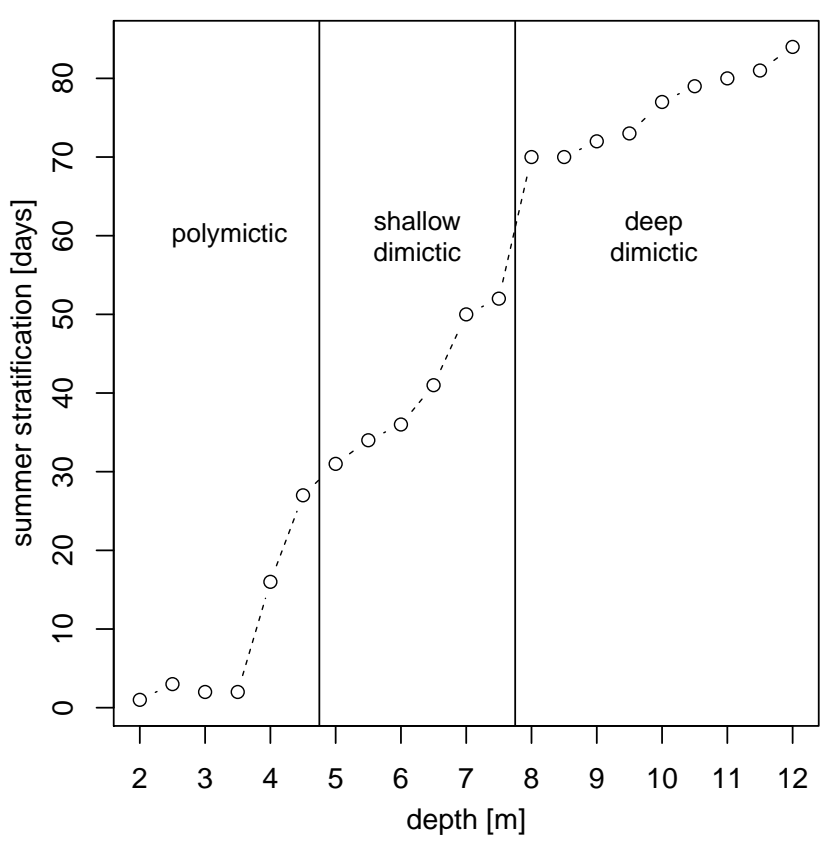

Figure 10. Total number of days with summer stratification in lakes of varying depths modeled with FLake driven by the meteorological data from the Samoylov observatory station for 2010. Existence of stratification was determined by the criterion $\left(T_{\mathrm{S}}-T_{\mathrm{b}}\right)>0.5^{\circ} \mathrm{C}$, where $T_{\mathrm{s}}$ and $T_{\mathrm{b}}$ are the modeled temperatures at lake surface and lake bottom, respectively.

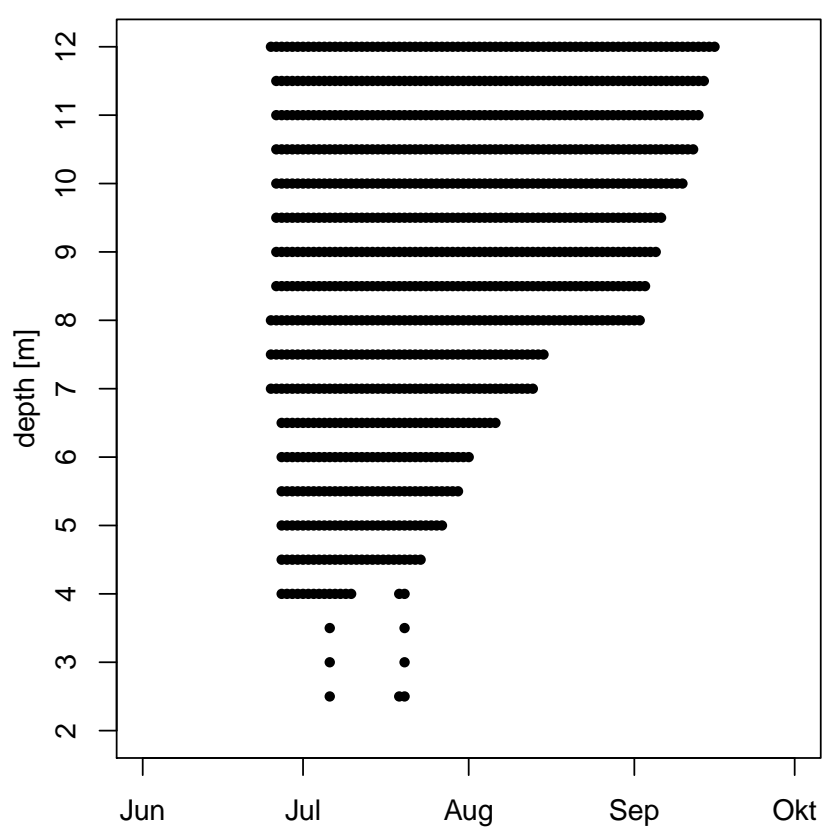

Figure 11. Summer stratification duration in lakes of varying depth (see Fig. 10 for definitions).

nal tundra landscape at this site takes several months and only reaches an average maximum thaw depth of about $0.6 \mathrm{~m}$ (Boike et al., 2013; Langer et al., 2013). Lakes also have an important effect on the subsurface thermal conditions beneath the lake and potentially also in the surrounding permafrost. Our results show that, during the summer, heat is continuously transferred from lake water into the bottom sediment. The importance of summer heat gain and its dissipation into the water body and the underlying sediment was first discussed by Vtyurina (1960), using data from a $12 \mathrm{~m}$ deep lake in Siberia. Her findings showed heat fluxes directed into the sediments during winter (Fig. 5 in Vtyurina, 1960; also reported in Grosse et al., 2013) which, according to our findings, is an indicator of permafrost thaw. Our modeling results, however, suggest that the temperature increase associated with permafrost thaw eventually results in a net annual heat equilibrium between deeper lakes and the underlying sediments, characterized by a continuous negative heat flux (i.e., heat loss from the sediment into the water column) during the long ice-covered winter and heat gain by the sediment during the open water summer period. The warming of lakebottom temperatures with the onset of ice cover was initially attributed by Brewer (1958) to heating by shortwave solar radiation and by Mortimer and Mackereth (1958) to the heat release from the lake sediment. Our observed near-bottom temperatures increased beneath the ice cover and the modeling experiments suggested this warming was solely due to heat flow from the sediment, with typical rates of $<10 \mathrm{~W} \mathrm{~m}^{-2}$. However, the heat flux from the sediment in tundra lakes appears to decay within less than 1 month, which is much faster than in ice-covered lakes of the temperate and boreal climates (cf. Rizk et al., 2014), and is followed by a gradual decrease of the deep water temperatures. The latter is not reproduced by the parameterized sediment module of FLake.

Our numerical modeling of the thermal dynamics of lakes has shown that the basic processes can be accurately reproduced for the summer. However, the model parameters that yielded the best fit for the seasonal heat budget and ice cover duration resulted in less accurate predictions of the bottom temperature under ice. Lake temperatures increase, starting in spring 1-2 months before ice-off, apparently by radiative solar heating. This temperature increase suggests that radiation can make a significant direct contribution to sediment heating in shallow and clear-water thermokarst lakes - a contribution that is usually neglected in lake models. The concept of self-similarity cannot account for the permafrost-talik specific lake processes, such as (i) warming of bottom waters immediately following onset of ice formation and (ii) phase change in the lake's frozen sediment, i.e., annual freeze thaw processes and thawing at the talik-permafrost boundary. While the short period of warming of bottom water during the ice-covered period is due to heat flux from the sediment into the water body, the cooling in winter from mid-winter onwards suggests a loss of heat. This heat loss may occur through conductive heat transfer into both the sediment and the atmosphere. In particular during winter the subsurface heat flux becomes a major component in the surface energy balance due to the lag of incoming short-wave radiation. The 


\section{ICE-FREE PERIOD}

\section{ICE-COVERED PERIOD}

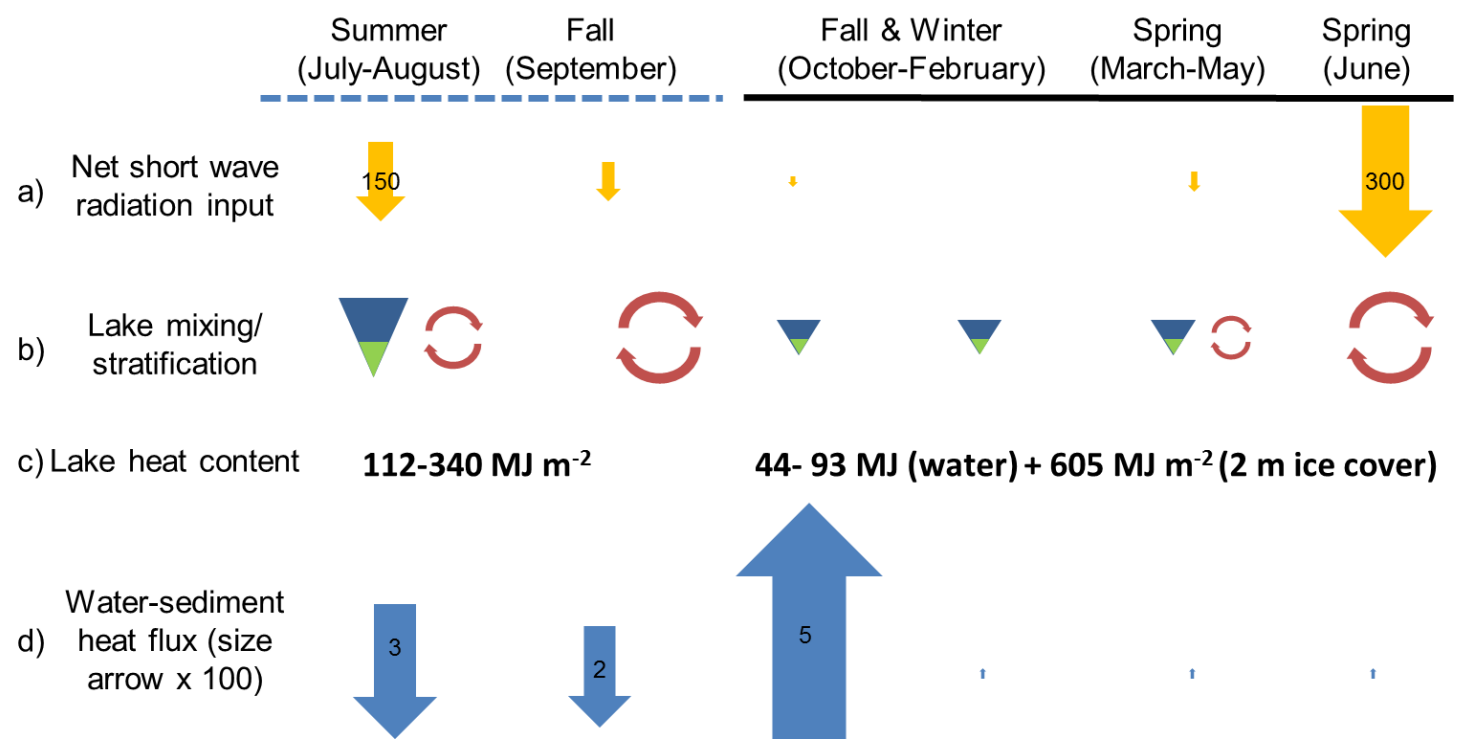

Figure 12. Summary of thermal processes in thermokarst lakes over a 1-year cycle. (a) Net short-wave radiation input (measured at the climate station on Samoylov); (b) dominant in-lake processes (mixing and stratification) - size of symbol reflects intensity of process; (c) lake heat content (divided into summer and winter lake heat content according to Wetzel, 2001); (d) average heat fluxes across the lake's water-sediment boundary: downward arrows denote heat flux into the sediment and upward arrows flux out of the sediment into the water column. The size of the arrows and their numbers indicate the relative magnitudes of the fluxes [W $\mathrm{m}^{-2}$ ]. Note that the sizes of arrows representing bottom heat fluxes have been enlarged by a factor of 100 due the small magnitude of the fluxes.

heat flux from ice-covered water bodies to the atmosphere can be much higher than the heat flux from snow covered soils (for example, shown by Langer et al. (2011b) for ponds and Jeffries et al. (1999) for Alaskan lakes) and can balance up to $90 \%$ of the radiative losses. Further investigations into these processes of warming and subsequent gradual cooling under the ice cover would require a more advanced lake model that is able to take into account deep, continuously frozen sediments and characteristic processes such as thawing.

\section{Summary and conclusions}

We have measured and modeled the thermal dynamics of lakes in the Lena River Delta of northern Siberia over a 3year period (2009-2012), with the objective of understanding and quantifying the important thermal processes that operate in this permafrost environment. The investigated lakes were situated in two different geomorphologic settings (sediments of the Pleistocene Ice Complex and on a younger river terrace) with a range of morphometric characteristics. Some of the lakes were seasonally connected to the Lena River through high floods that occurred during spring. Such annual flooding of these lakes by cold river water results in a significant reduction in the ongoing warming (and thus sensible heat storage), depending on the magnitude of the flooding. A schematic summary of our results is provided in Fig. 12.

The lakes were shown to receive substantial energy for warming from net shortwave radiation during the summer. Warming also occurs during the ice cover period in spring, resulting in convective mixing beneath the ice cover. Mixing also occurs following ice break-up, during the summer, and during the fall cooling, resulting in efficient heat transfer to bottom waters and across the sediment-water interface. Numerical modeling suggests that the annual mean net heat flux across the bottom sediment boundary is approximately zero, with positive summer downward fluxes during the icefree period (4 months) and heat-release back into the water column at much lower rates during the ice-covered period (8 months). Overall, the ice formation and thaw together account for most of the annual variations in a lake's heat content. Furthermore, their timing and durations determine the magnitude and direction of bottom sediment heat fluxes and the timing of water column mixing. Future warming may result in changes to the ice cover but may also produce more pronounced summer stratification, thus potentially reducing the heat input into the sediment layers.

In view of the large area covered by water bodies in permafrost landscapes (25\% of the land surface) and their efficiency at energy absorption and mixing, these water bodies are clearly of considerable importance with respect to energy 
storage and turnover, atmospheric fluxes, and sediment heat fluxes in permafrost landscapes.

The investigated thermokarst lakes are representative of Arctic tundra lowlands characterized by thermokarst processes that are common for large regions in central and eastern Siberia, interior and northern Alaska as well as northwest Canada. Despite their importance, however, lakes are not yet included in earth system models. Future work should therefore include lakes in these models and test their sensitivity to possible future changes in climate.

\section{Data availability}

The data are available in the Supplement for this paper and through the PANGAEA website (doi:10.1594/PANGAEA.846525). 


\section{Appendix A: Morphometry of lakes, hourly lake temperatures and lowest sensor depths data}

The topographic slope on the polygonal tundra (first terrace) is very low $\left(<5^{\circ}\right)$. Aerial images of Sa_Lake_2 and Sa_Lake_3 show submerged polygons beneath the water surface, indicating that these lakes are likely to have been formed by the thawing of ground ice and ice wedges and the subsequent merging of polygonal ponds. The shorelines adjacent to shallow parts of these younger thermokarst lakes (with depths of $0-3 \mathrm{~m}$ ) are very irregular and feature protrusions of different shapes and sizes (Figs. A1-A4). Where deeper sections (>3 m) occur close to the shore, the shorelines are smooth and the lakes tend to have an oval shape. The profiles of thermokarst lakes tend to be V-shaped rather than flat-bottomed and the thermokarst lakes investigated were up to $6.4 \mathrm{~m}$ deep. The deepest lake on this island, with up to $11.6 \mathrm{~m}$ water depth, is Sa_Lake_4. It has an elongated shape and is one of three interconnected lakes that occur in an abandoned channel of the Lena River ("oxbow" or "perched" lakes; Fig. A4). The largest monitored lake in this series of lakes was $\mathrm{Ku} \_L a k e \_1$, located on sediments of the Pleistocene Ice Complex, which have high ice content. This lake is the largest of three residual lakes located within an alas that is more than $20 \mathrm{~m}$ deep. This thermokarst basin evolved in two phases (Morgenstern et al., 2013). In the first phase the original large lake covered the entire basin. It drained abruptly through a thermos-erosional valley at about $5.7 \mathrm{ka} \mathrm{BP}$, leaving the $>20 \mathrm{~m}$ deep alas with residual lakes. This was then followed by thermokarst processes of varying intensity during the second phase (5.7 ka BP to the present). This lake is an order of magnitude larger in surface area than the other four thermokarst lakes investigated and, in contrast to those lakes on Samoylov Island, has a regular oval shape, occurs within a basin with steep sides and has a smooth, flat shoreline. The maximum water depth is about $3.6 \mathrm{~m}$ and the profile is flat-bottomed (Fig. A5).

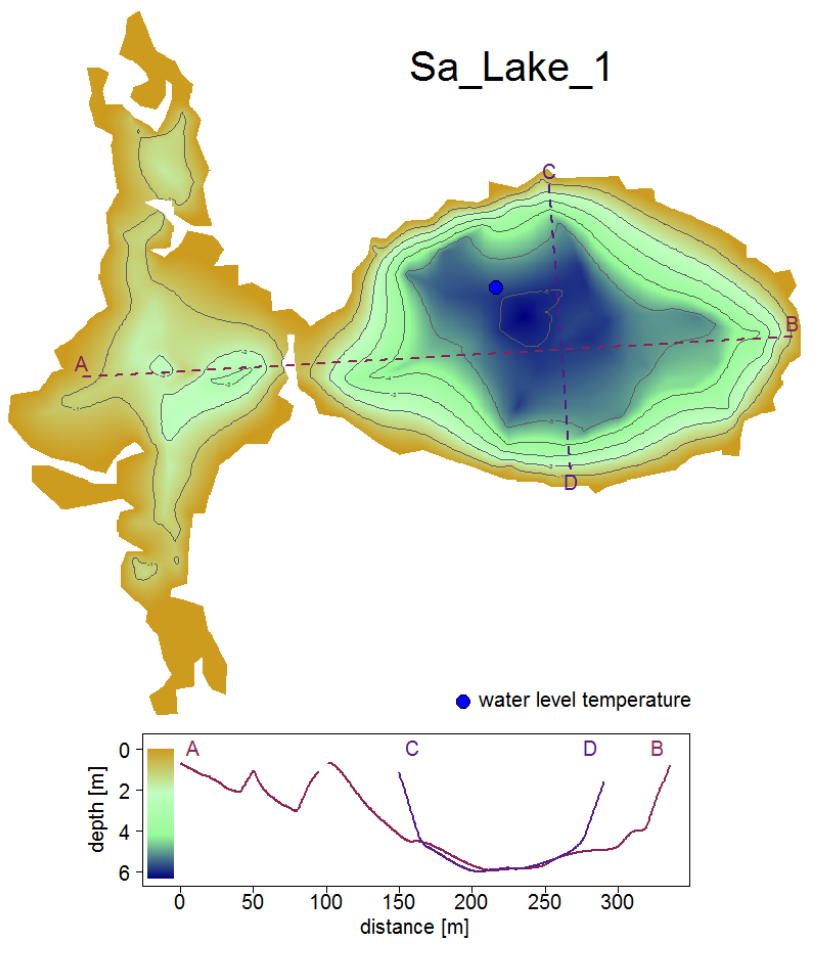

Figure A1. Bathymetry and cross sections of Sa_Lake_1 with location of sensors.

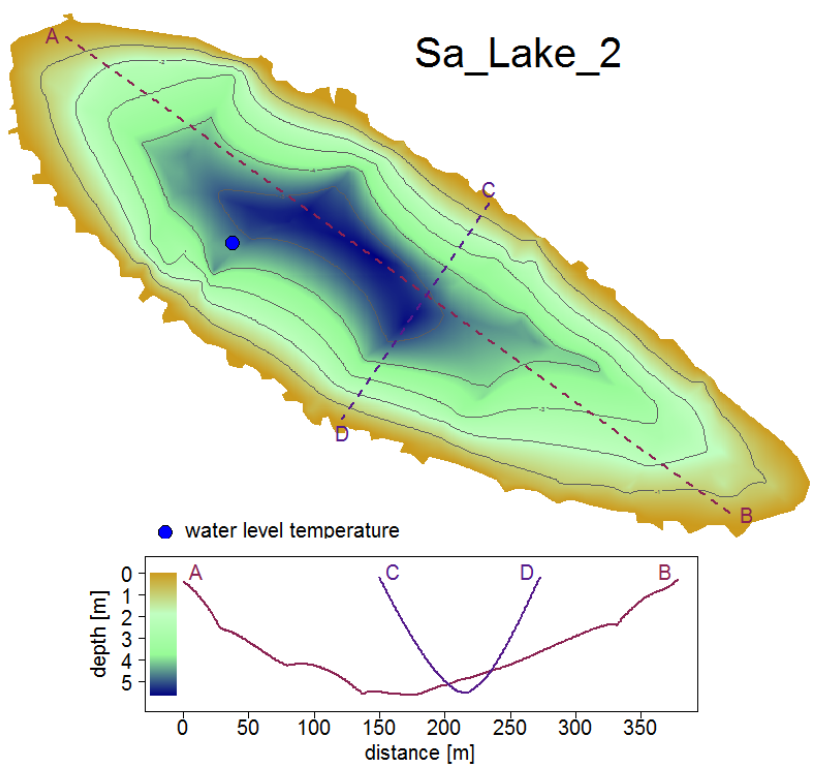

Figure A2. Bathymetry and cross sections of Sa_Lake_2 with location of sensors. 

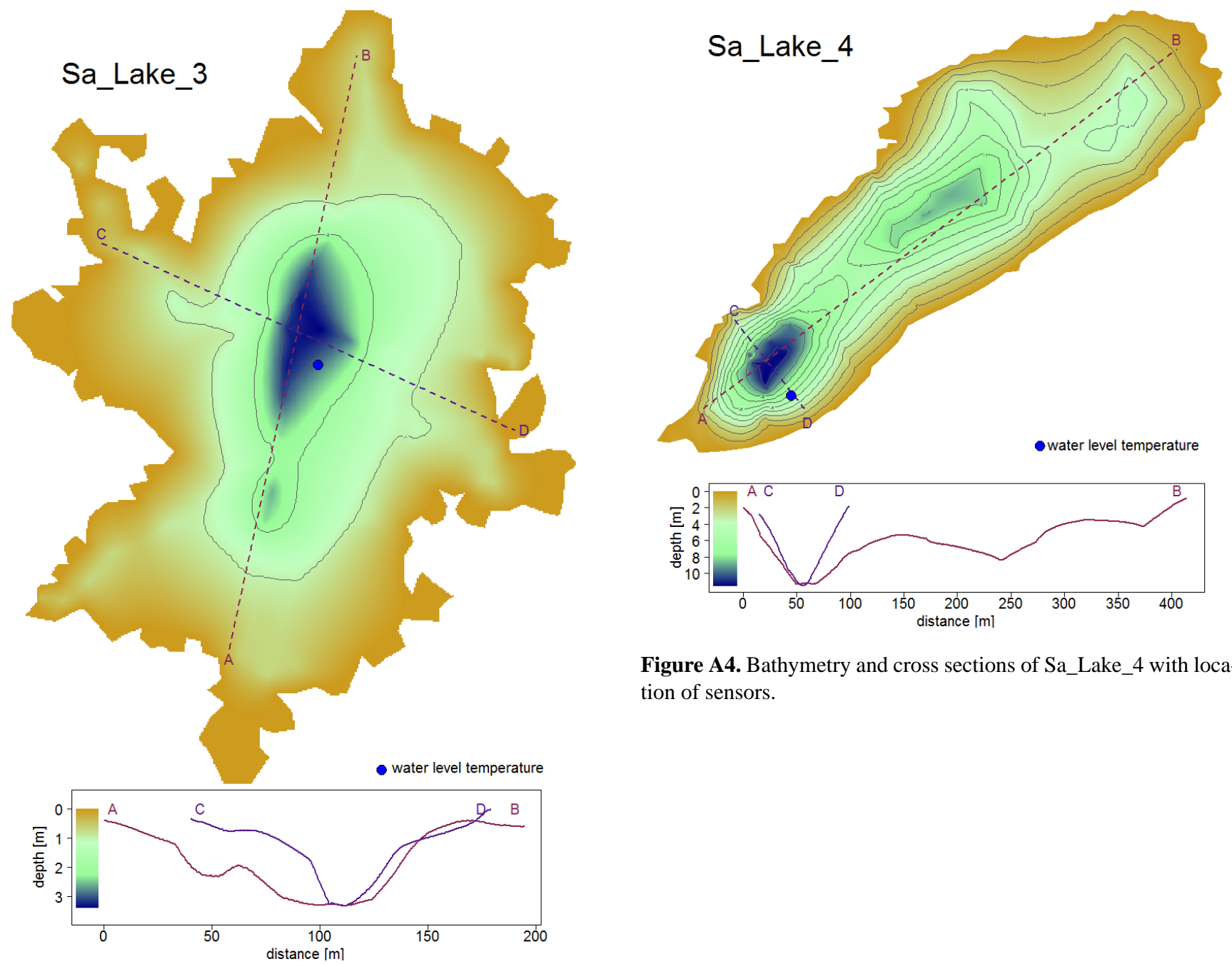

Figure A4. Bathymetry and cross sections of Sa_Lake_4 with location of sensors.

Figure A3. Bathymetry and cross sections of Sa_Lake_3 with location of sensors. 


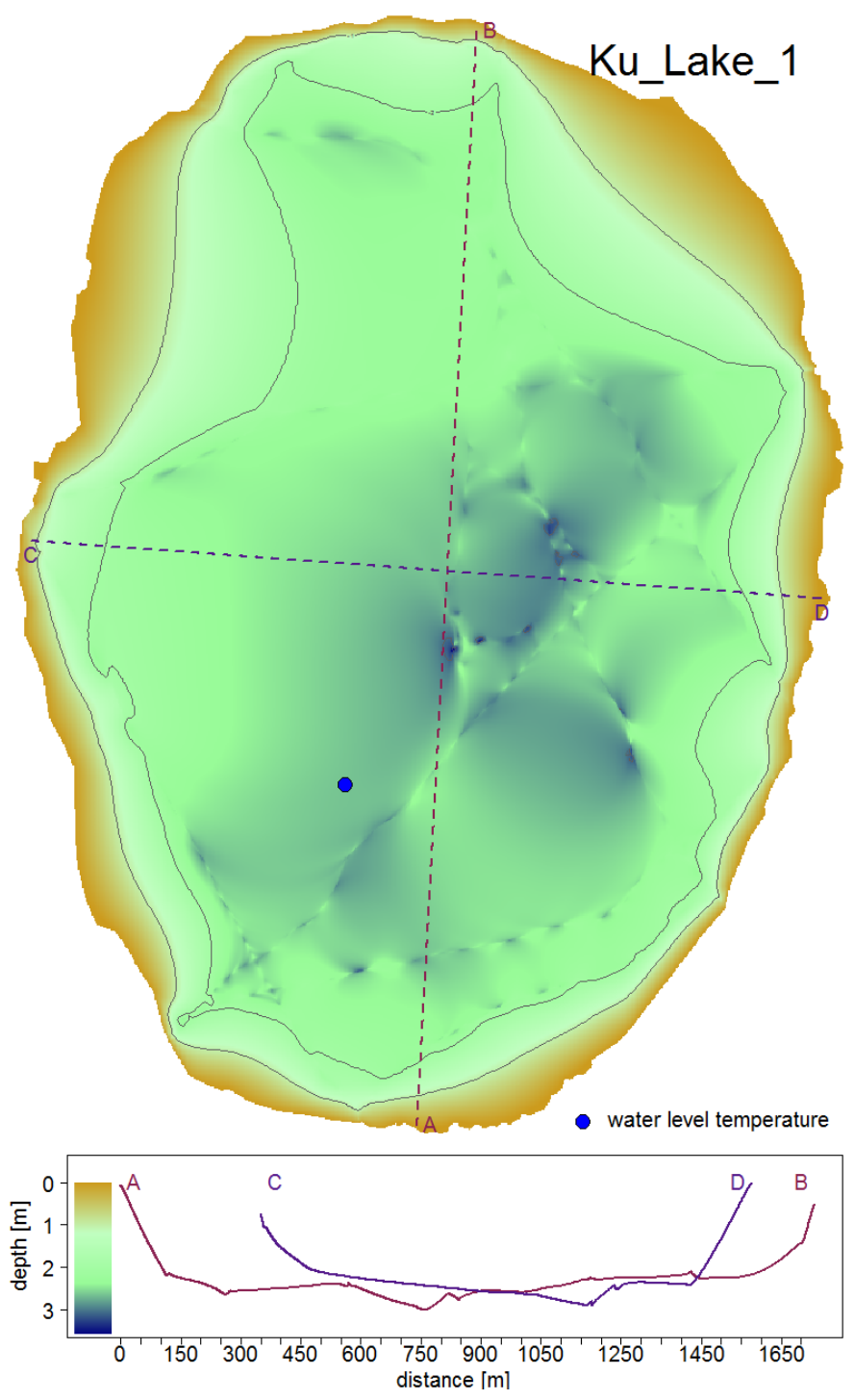

Figure A5. Bathymetry and cross sections of Ku_Lake_1. Data from Morgenstern et al. (2011) and 10.1594/PANGAEA.848485. 


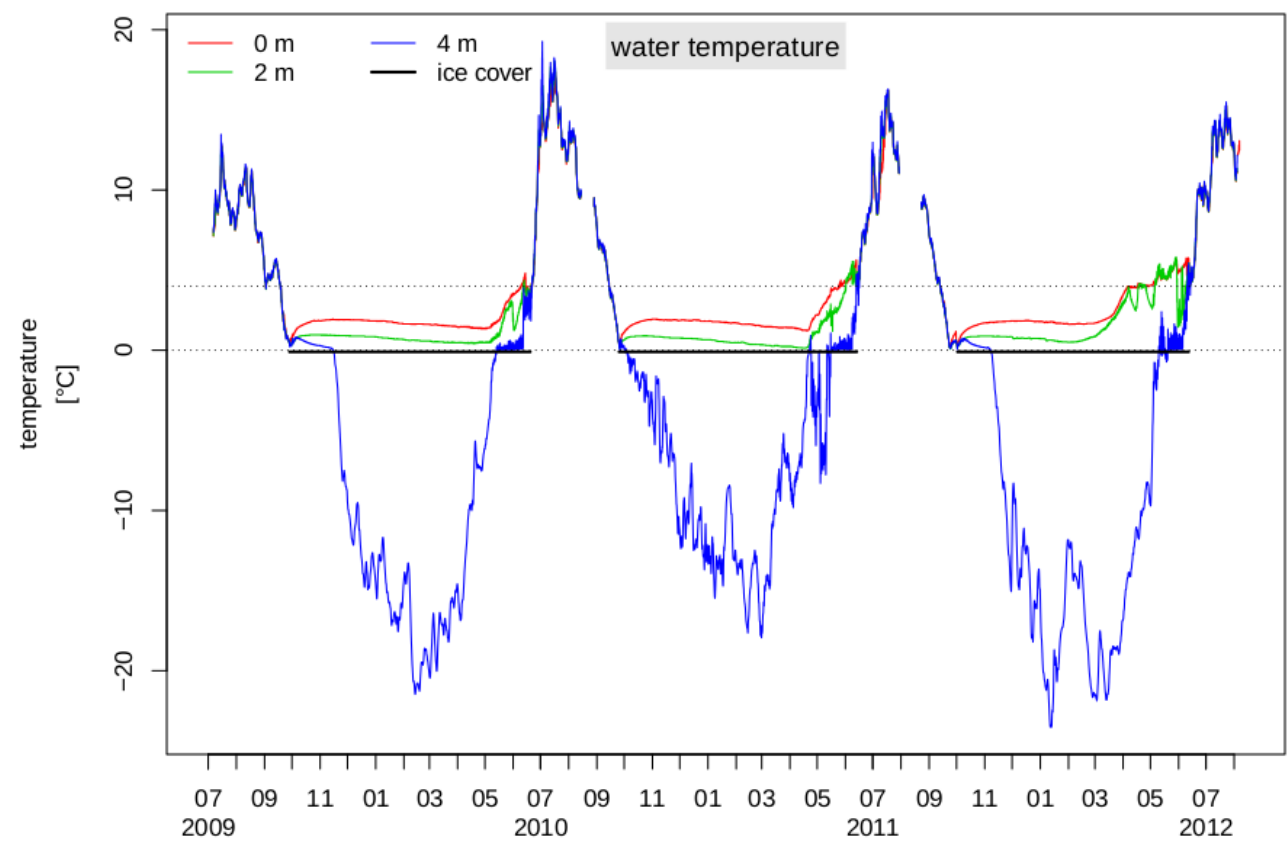

Figure A6. Hourly lake temperatures for Sa_Lake_2, from July 2009 to August 2012. Thick black lines indicate ice-covered periods.

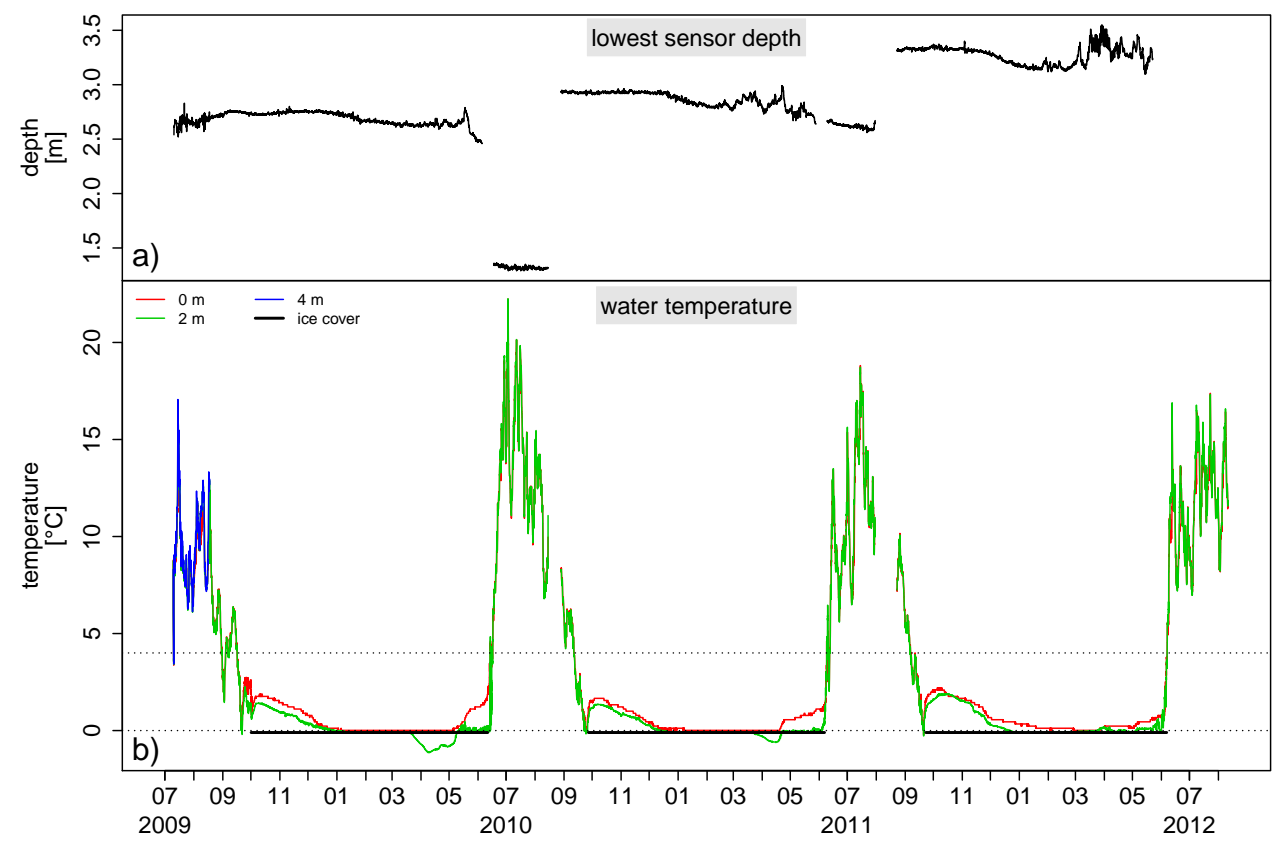

Figure A7. Hourly lake temperatures and lowest sensor depth (indicating water level changes) for Sa_Lake_3, from July 2009 to August 2012. Thick black lines indicate ice-covered periods. 


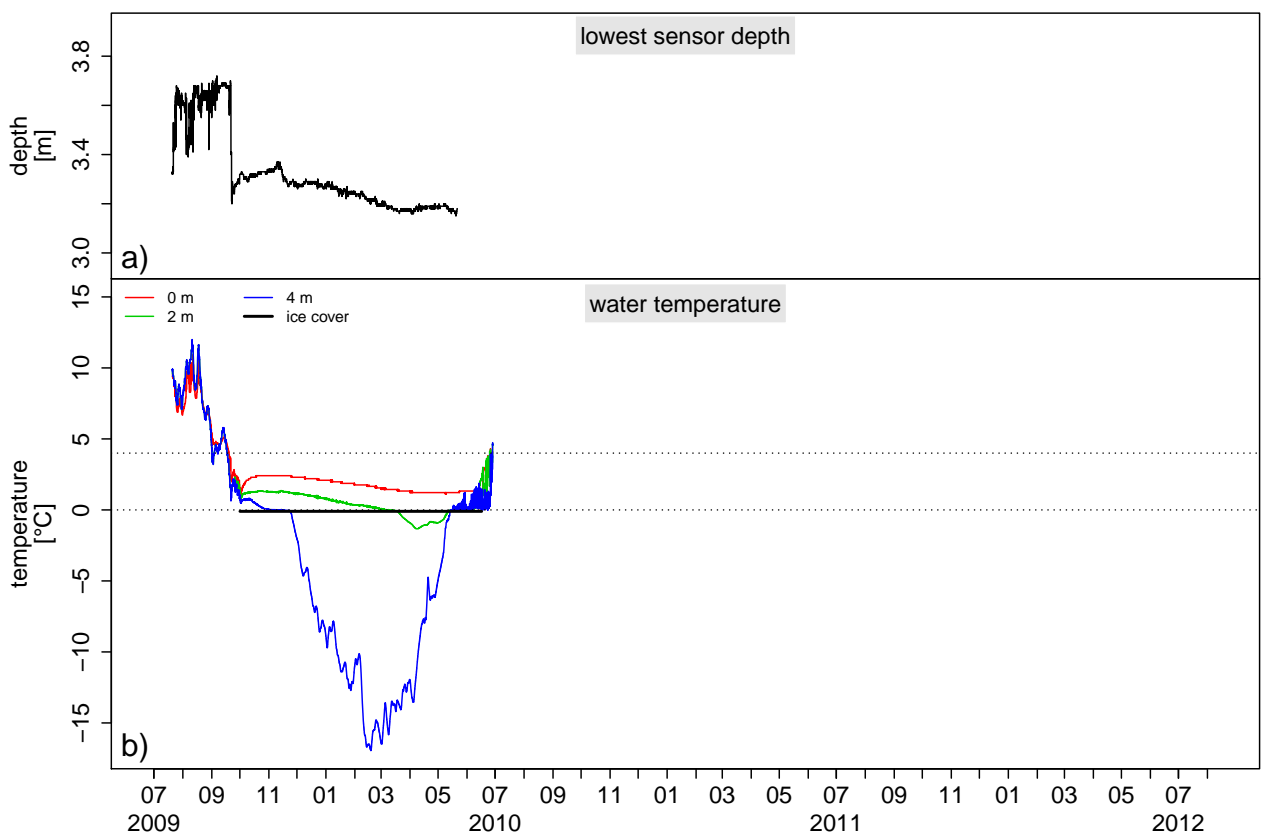

Figure A8. Hourly lake temperatures and lowest sensor depth (indicating water level changes) for Ku_Lake_1, from July 2009 to August 2010. Thick black lines indicate ice-covered periods. 


\section{Information about the supplement}

- Model data input (Samoylov); air temperature, air humidity, wind speed; radiation components Samoylov_2009_2012.dat

- Model validation data: hourly lake temperatures and sensor depth (lake water level) data, where measured

Sa_Lake_1_2009_2012.dat

Sa_Lake_2_2009_2012.dat

Sa_Lake_3_2009_2012.dat

Sa_Lake_4_2009_2012.dat

Ku_Lake_1_2009_2010.dat

LenaRiver_2009_2010.dat

- Animation (movie) of temperatures in Sa_Lake_1 using daily average temperatures at depth and interpolated between depths using cubic interpolation. Daily temperature plots were added to produce the animation of temperatures Sa_Lake_1_2010-daily-color-.2s.gif

- Summary table of mean monthly air and bottom lake temperatures: meanlake_air_temp.txt

\section{The Supplement related to this article is available online at doi:10.5194/bg-12-5941-2015-supplement.}

Author contributions. J. Boike designed the research and led the discussions, supported by G. Kirilin and M. Langer. The FLake modeling was carried out by G. Kirilin and C. Georgi. The paper was written by J. Boike, with comments from all authors.

Acknowledgements. The logistical support provided by the Russian Research station on Samoylov Island is gratefully acknowledged. Field support, including data collection, was provided by Grigoriy Soloviev, Waldemar Schneider, Günther Stoof, and Karoline Wischnewski. Elizabeth Miller, Max Heikenfeld, Wil Lieberman-Cribbin and Stephan Lange assisted with the data analysis and helpful discussions. The authors acknowledge the financial support provided through the European Union's FP7-ENV PAGE21 project under contract number GA282700, and through the Feodor Lynen grant from the Alexander-von-Humboldt Foundation awarded to Moritz Langer. The research was carried out under the Russian government's Program of Competitive Growth, Kazan Federal University.

Edited by: V. Brovkin

\section{References}

Abnizova, A., Siemens, J., Langer, M., and Boike, J.: Small ponds with major impact: The relevance of ponds and lakes in permafrost landscapes to carbon dioxide emissions, Global Biogeochem. Cy., 26, GB2041, doi:10.1029/2011gb004237, 2012.
Alekseevsky, N. I. (Ed.): Geoecological state of Russian Arctic coast and their safety of nature management, GEOS Publ., Moscow, Russia, 586 pp., 2007 (in Russian).

Alerstam, T., Gudmundsson, G. A., Green, M., and Hedenström, A.: Migration along orthodromic sun compass routes by arctic birds, Science, 291, 300-303, 2001.

Are F. E.: Thermal regime of small thermokarst lakes in the Siberian Taiga zone (for example of Central Yakutia), Collection of papers "Lakes of Cryolithozone of Siberia", edited by: Are F. E., Nauka, Siberian brunch, 98-116, 1974 (in Russian).

Arp, C. D., Jones, B. M., Whitman, M., Larsen, A., and Urban, F. E.: Lake Temperature and Ice Cover Regimes in the Alaskan Subarctic and Arctic: Integrated Monitoring, Remote Sensing, and Modeling, J. Am. Water Resour. Ass., 46, 777-791, doi:10.1111/j.1752-1688.2010.00451.x, 2010.

Arp, C. D., Jones, B. M., Lu, Z., and Whitman, M. S.: Shifting balance of thermokarst lake ice regimes across the Arctic Coastal Plain of northern Alaska, Geophys. Res. Lett., 39, L16503, doi:10.1029/2012gl052518, 2012.

Boike, J., Wille, C., and Abnizova, A.: Climatology and summer energy and water balance of polygonal tundra in the Lena River Delta, Siberia, J. Geophys. Res., 113, G03025, doi:10.1029/2007JG000540, 2008.

Boike, J., Kattenstroth, B., Abramova, K., Bornemann, N., Chetverova, A., Fedorova, I., Fröb, K., Grigoriev, M., Grüber, M., Kutzbach, L., Langer, M., Minke, M., Muster, S., Piel, K., Pfeiffer, E.-M., Stoof, G., Westermann, S., Wischnewski, K., Wille, C., and Hubberten, H.-W.: Baseline characteristics of climate, permafrost and land cover from a new permafrost observatory in the Lena River Delta, Siberia (1998-2011), Biogeosciences, 10, 2105-2128, doi:10.5194/bg-10-2105-2013, 2013.

Burn, C. R.: Tundra Lakes and Permafrost, Richards Island, Western Arctic Coast, Canada, Can. J. Earth Sci., 39, 1281-1298, doi:10.1139/E02-035, 2002.

Burn, C. R.: Lake-bottom Thermal Regimes, Western Arctic Coast, Canada, Permafrost Periglac., 16, 355-367, doi:10.1002/PPP.542, 2005.

Brewer, M. C.: The thermal regime of an arctic lake, EOS Transactions, American Geophysical Union, 39, 2, 278-284, doi:10.1029/TR039i002p00278, 1958.

Costard, F. and Gautier, E.: The Lena River: Hydromorphodynamic Features in a Deep Permafrost Zone, in: Large Rivers: Geomorphology and Management, edited by: Gupta, A., John Wiley \& Sons, Ltd, West Sussex, England, 225-233, 2007.

Chetverova, A., Fedorova, I., Potapova, T., and Boike, J.: Hydrological and geochemical features of lakes of Samoylov Island of the Lena River Delta, Proceedings of AARI, no. 1, 97-110, 2013 (in Russian)

Ensom, T. P., Burn, C. R., and Kokelj, S. V.: Lake- and channelbottom temperatures in the Mackenzie Delta, Northwest Territories, Can. J. Earth Sci., 49, 963-978, doi:10.1139/e2012-001, 2012.

Fedorova, I., Chetverova, A., Bolshiyanov, D., Makarov, A., Boike, J., Heim, B., Morgenstern, A., Overduin, P. P., Wegner, C., Kashina, V., Eulenburg, A., Dobrotina, E., and Sidorina, I.: Lena Delta hydrology and geochemistry: long-term hydrological data and recent field observations, Biogeosciences, 12, 345-363, doi:10.5194/bg-12-345-2015, 2015. 
Golosov, S. and Kirillin, G.: A parameterized model of heat storage by lake sediments, Environ. Modell. Software, 25, 793-801, doi:10.1016/j.envsoft.2010.01.002, 2010.

Golosov, S., Terzhevik, A., Zverev, I., Kirillin, G., and Engelhardt, C.: Climate change impact on thermal and oxygen regime of shallow lakes, Tellus A, 64, 17264, doi:10.3402/tellusa.v64i0.17264, 2012.

Gordeev, V. V. and Sidorov, I. S.: Concentrations of major elements and their outflow into the Laptev Sea by the Lena River, Mar. Chem., 43, 33-45, 1993.

Grigoriev, M.: Cryomorphogenesis of the Lena River mouth area, Siberian Branch, USSR Academy of Sciences, Yakutsk, 176 pp., 1993 (in Russian).

Grigoriev, N. F.: The temperature of permafrost in the Lena delta basin-deposit conditions and properties of the permafrost in Yakutia, Yakutsk, 2, 97-101, 1960 (in Russian).

Grigoriev, N. F. Perennially frozen rocks of the maritime lowlands of Yakutia, Moscow, Nauka, 80 pp., 1966 (in Russian).

Grosse, G., Jones, B., and Arp, C. D.: Thermokarst Lakes, Drainage, and Drained Basins, in: Treatise on Geomorphology, edited by: Giardino, R. and Harbor, J., 8, Glacial and Periglacial Geomorphology, 29, 325-353, Academic Press, San Diego, CA, doi:10.1016/B978-0-12-374739-6.00216-5, 2013.

Harris, S. A.: Causes and consequences of rapid thermokarst development in permafrost or glacial terrain, Permafrost Periglac., 13, 237-242, doi:10.1002/ppp.419, 2002.

Hinkel, K. M., Lenters, J. D., Sheng, Y., Lyons, E. A., Beck, R. A., Eisner, W. R., Maurer, E. F., Wang, J., and Potter, B. L.: Thermokarst Lakes on the Arctic Coastal Plain of Alaska: Spatial and Temporal Variability in Summer Water Temperature, Permafrost Periglac., 23, 207-217, doi:10.1002/ppp.1743, 2012.

Hobbie, J. E. and Kling, G. W.: Alaska's changing Arctic: Ecological consequences for tundra, streams, and lakes, Oxford University Press, Oxford, New York, 352 pp., 2014.

Jeffries, M. O., Zhang, T., Frey, K., and Kozlenko, N.: Estimating Late-Winter Heat Flow to the Atmosphere from the LakeDominated Alaskan North Slope, J. Glaciol., 45, 315-347, 1999.

Jorgenson, M. T., Romanovsky, V., Harden, J., Shur, Y., O’Donnell, J., Schuur, E. A. G., Kanevskiy, M., and Marchenko, S.: Resilience and vulnerability of permafrost to climate change, Can. J. Forest Res., 40, 1219-1236, doi:10.1139/x10-060, 2010.

Kalnay, E., Kanamitsu, M., Kistler, R., Collins, W., Deaven, D., Gandin, L., Iredell, M., Saha, S., White, G., Woollen, J., Zhu, Y., Leetmaa, A., Reynolds, R., Chelliah, M., Ebisuzaki, W., Higgins, W., Janowiak, J., Mo, K. C., Ropelewski, C., Wang, J., Jenne, R., and Joseph, D.: The NCEP/NCAR 40-Year Reanalysis Project, B. Am. Meteorol. Soc., 77, 437-471, 1996.

Keatley, B. E., Douglas, M. S. V., and Smol, J. P.: Physical and chemical limnological characteristics of lakes and ponds across environmental gradients on Melville Island, Nunavut/N.W.T., High Arctic Canada, Fund. Appl. Limnol., 168, 355-376, doi:10.1127/1863-9135/2007/0168-0355, 2007.

Kirillin, G.: Modeling the impact of global warming on water temperature and seasonal mixing regimes in small temperate lakes, Boreal Environ. Res., 15, 279-293, 2010.

Kirillin, G., Leppäranta, M., Terzhevik, A., Granin, N., Bernhardt, J., Engelhardt, C., Efremova, T., Golosov, S., Palshin, N., and Sherstyankin, P.: Physics of seasonally ice-covered lakes: a review, Aquat. Sci., 74, 659-682, 2012.
Lachenbruch, A. H.: Mechanics of thermal contraction cracks and ice-wedge polygons in permafrost, Special papers, 70, Geological Society of America, New York, 69 pp., 1962.

Langer, M., Westermann, S., Muster, S., Piel, K., and Boike, J.: The surface energy balance of a polygonal tundra site in northern Siberia - Part 1: Spring to fall, The Cryosphere, 5, 151-171, doi:10.5194/tc-5-151-2011, 2011a.

Langer, M., Westermann, S., Muster, S., Piel, K., and Boike, J.: The surface energy balance of a polygonal tundra site in northern Siberia - Part 2: Winter, The Cryosphere, 5, 509-524, doi:10.5194/tc-5-509-2011, 2011b.

Langer, M., Westermann, S., Heikenfeld, M., Dorn, W., and Boike, J.: Satellite-based modeling of permafrost temperatures in a tundra lowland landscape, Remote Sens. Environ., 135, 12-24, doi:10.1016/j.rse.2013.03.011, 2013.

Langer, M., Westermann, S., Walter Anthony, K., Wischnewski, K., and Boike, J.: Frozen ponds: production and storage of methane during the Arctic winter in a lowland tundra landscape in northern Siberia, Lena River delta, Biogeosciences, 12, 977-990, doi:10.5194/bg-12-977-2015, 2015.

Laurion, I., Vincent, W. F., Retamal, L., Dupont, C., Francus, P., MacIntyre, S., and Pienitz, R.: Variability in greenhouse gas emissions from permafrost thaw ponds, Limnol. Oceanogr., 55, 115-133, 2010.

Lehner, B. and Döll, P.: Development and validation of a global database of lakes, reservoirs and wetlands, J. Hydrol., 296, 1-22, 2004.

Ling, F. and Zhang, T.: Numerical simulation of permafrost thermal regime and talik development under shallow thaw lakes on the Alaskan Arctic Coastal Plain, J. Geophys. Res., 108, 4511, doi:10.1029/2002JD003014, 2003.

Luecke, C., Giblin, A. E., Bettez, N. D., Burkart, G. A., Crump, B. C., Evans, M. A., Gettel, G., McIntyre, S., O’Brien, W. J., Rublee, P. A., and King, G. W.: The response of lakes near the Arctic LTER to environmental change, in: Alaska's changing Arctic: ecological consequences for tundra, streams, and lakes, edited by: Hobbie, J. and Kling, G. W., Oxford University Press, New York, 238-286, 2014.

Martynov, A., Sushama, L., and Laprise, R.: Simulation of temperate freezing lakes by one-dimensional lake models: performance assessment for interactive coupling with regional climate models, Boreal Environ. Res., 15, 143-164, 2010.

Martynov, A., Sushama, L., Laprise, R., Winger, K., and Dugas, B.: Interactive lakes in the Canadian Regional Climate Model, version 5: the role of lakes in the regional climate of North America, Tellus A, 64, 16226, doi:10.3402/tellusa.v64i0.16226, 2012.

Mironov, D. V.: Parameterization of lakes in numerical weather prediction. Description of a lake model, COSMO technical report, Technical Report No. 11, August 2008, http://www. cosmo-model.org/content/model/documentation/techReports/ (last access: 6 July 2015), 2008.

Mironov, D. V., Terzhevik, A., Kirillin, G., Jonas, T., Malm, J., and Farmer, D.: Radiatively driven convection in ice-covered lakes: Observations, scaling, and a mixed layer model, J. Geophys. Res.-Oceans, 107, 1-16, doi:10.1029/2001JC000892, 2002.

Mironov, D., Ritter, B., Schulz, J.-P., Buchhold, M., Lange, M., and Machulskaya, E.: Parameterization of sea and lake ice in numerical weather prediction models of the German Weather Service, Tellus A, 64, 17330, doi:10.3402/tellusa.v64i0.17330, 2012. 
Morgenstern, A., Grosse, G., Günther, F., Fedorova, I., and Schirrmeister, L.: Spatial analyses of thermokarst lakes and basins in Yedoma landscapes of the Lena Delta, The Cryosphere, 5, 849-867, 10,

http://www.the-cryosphere-discuss.net/5/849/10/.5194/tc-5-8492011, 2011.

Morgenstern, A., Ulrich, M., Günther, F., Roessler, S., Fedorova, I. V., Rudaya, N. A., Wetterich, S., Boike, J., and Schirrmeister, L.: Evolution of thermokarst in East Siberian icerich permafrost: A case study, Geomorphology, 201, 363-379, doi:10.1016/j.geomorph.2013.07.011, 2013.

Mortimer, C. and Mackereth, F: Convection and its consequences in ice-covered lakes, Verh. Int. Ver. Limnol., 13, 923-932, 1958.

Muster, S., Langer, M., Heim, B., Westermann, S., and Boike, J.: Subpixel heterogeneity of ice-wedge polygonal tundra: a multi-scale analysis of land cover and evapotranspiration in the Lena River Delta, Siberia, Tellus B, 64, 17301, doi:10.3402/tellusb.v64i0.17301, 2012.

Nolan, M. and Brigham-Grette, J.: Basic hydrology, limnology, and meteorology of modern Lake El'gygytgyn, Siberia, J. Paleolimnol., 37, 17-35, doi:10.1007/s10933-006-9020-y, 2006.

Oveisy, A. and Boegman, L.: One-dimensional simulation of lake and ice dynamics during winter, J. Limnol., 73, 441-453, doi:10.4081/jlimnol.2014.903, 2014.

Pavlov, A. V. and Tishin, M. I.: Heat balance of a large lake and surrounding area in central Yakutia, Collection of papers "Structure and thermal regime of frozen rocks", edited by: Katasonova, E. G., Pavlov, A. V., Nauka, Siberian branch, 53-62, 1981 (in Russian).

Pienitz, R., Smol, J. P., and Lean, D. R. S.: Physical and Chemical limnology of 59 lakes located between the southern Yukon and the Tuktoyaktuk Peninsula, Northwest Territories (Canada), Can. J. Fish. Aquat. Sci., 54, 330-346, 1997.

Rawlins, M. A., Serreze, M. C., Schroeder, R., Zhang, X., and McDonald, K. C.: Diagnosis of the record discharge of Arcticdraining Eurasian rivers in 2007, Environ. Res. Lett., 4, 1-8, 2009.

Read, J. S., Hamilton, D. P., Jones, I. D., Muraoka, K., Winslow, L. A., Kroiss, R., Wu, C. H., and Gaiser, E.: Derivation of lake mixing and stratification indices from highresolution lake buoy data, Environ. Modell. Soft., 26, 13251336, doi:10.1016/j.envsoft.2011.05.006, 2011.

Rizk, W., Kirillin, G., and Leppäranta, M.: Basin-scale circulation and heat fluxes in ice-covered lakes, Limnol. Oceanogr., 59, 445464, 2014.

Sepulveda-Jauregui, A., Walter Anthony, K. M., Martinez-Cruz, K., Greene, S., and Thalasso, F.: Methane and carbon dioxide emissions from 40 lakes along a north-south latitudinal transect in Alaska, Biogeosciences, 12, 3197-3223, doi:10.5194/bg-123197-2015, 2015.

Schertzer, W. M.: Freshwater Lakes, in: Surface climates of Canada, edited by: Bailey, W. G., Oke, T. R., and Rouse, W. R., McGillQueens University Press, Montreal, 124-148, 1997.

Schneider von Deimling, T., Grosse, G., Strauss, J., Schirrmeister, L., Morgenstern, A., Schaphoff, S., Meinshausen, M., and Boike, J.: Observation-based modelling of permafrost carbon fluxes with accounting for deep carbon deposits and thermokarst activity, Biogeosciences, 12, 3469-3488, doi:10.5194/bg-12-34692015, 2015.
Schwamborn, G., Rachold, V., and Grigoriev, M. N.: Late Quaternary sedimentation history of the Lena Delta, Quatern. Int., 89, 119-134, doi:10.1016/S1040-6182(01)00084-2, 2002.

Sobiech, J., Boike, J., and Dierking, W.: Observation of melt onset in an Arctic Tundra landscape using high resolution TerraSAR$\mathrm{X}$ and RADARSAT-2 data, IGARSS, Munich, Germany, 35523555, 2012.

Spigel, R. H. and Imberger, J. The classification of mixed-layer dynamics of lakes of small to medium size, J. Phys. Oceanogr., 10, 1104-1121, 1980.

Stepanenko, V. M., Goyette, S., Martynov, A., Perroud, M., Fang, X., and Mironov, D.: First steps of a lake model intercomparison Project: LakeMIP, Boreal. Environ. Res., 15, 191-202, 2010.

Thiery, W., Stepanenko, V. M., Fang, X., Jöhnk, K. D., Li, Z., Martynov, A., Perroud, M., Subin, Z. M., Darchambeau, F., Mironov, D., and van Lipzig, N. P. M.: LakeMIP Kivu: evaluating the representation of a large, deep tropical lake by a set of one-dimensional lake models, 66, 21390, doi:10.3402/tellusa.v66.21390, 2014.

Vincent, A. C., Mueller, D. R., and Vincent, W. F.: Simulated heat storage in a perennially ice-covered high Arctic lake: Sensitivity to climate change, J. Geophys. Res., 113, C04036, doi:10.1029/2007JC004360, 2008.

Vincent, W. F., Pienitz, R., Laurion, I., and Walter Anthony, K.: Climate impacts on Arctic lakes, in: Climatic Change and Global Warming of Inland Waters: Impacts and Mitigation for Ecosystems and Societies, edited by: Goldman, C. R., Kumagai, M., and Robarts, R. D., John Wiley \& Sons, Ltd, Chichester, UK, 27-42, 2013.

Vtyurina, E. A.: Temperature regime of the Lake Glubokoe, Trudy institute merzlotovedeniya im, V.A. Obrucheva, Academia Nauk SSSR, Moscow, 132-140, 1960 (in Russian).

Walsh, S. E., Vavrus, S. J., Foley, J. A., Fisher, V. A., Wynne, R. H., and Lenters, J. D.: Global Patterns of Lake Ice Phenology and Climate: Model Simulation and Observation, J. Geophys. Res., 103, 825-828, 1998.

Walter, K. M., Zimov, S. A., Chanton, J. P., Verbyla, D., and Chapin III, F. S.: Methane bubbling from Siberian thaw lakes as a positive feedback to climate warming, Nature, 443, 71-75, doi:10.1038/nature05040, 2006.

Welch, H. E. and Bergmann, M. A.: Water circulation in small arctic lakes in winter, Can. J. Fish. Aquat. Sci., 42, 506-520, 1985.

Wetterich, S., Schirrmeister, L., Meyer, H., Andreas, F. A., and Mackensen, A.: Arctic freshwater ostracods from modern periglacial environments in the Lena River Delta (Siberian Arctic, Russia): geochemical applications for palaeoenvironmental reconstructions, J. Paleolimnol., 39, 427-449, doi:10.1007/s10933-007-9122-1, 2008.

Wetzel, R. G.: Limnology: lake and river ecosystems, 3rd Edn., Gulf Professional Publishing, Orlando, 1006 pp., 2001.

Yi, S., Wischnewski, K., Langer, M., Muster, S., and Boike, J.: Freeze/thaw processes in complex permafrost landscapes of northern Siberia simulated using the TEM ecosystem model: impact of thermokarst ponds and lakes, Geosci. Model Dev., 7, 1671-1689, doi:10.5194/gmd-7-1671-2014, 2014. 